\title{
INTERVENÇÃO POLÍTICA NA SENTENÇA DO DIREITO? OS FUNDAMENTOS CULTURAIS DA PENA MÍNIMA ${ }^{1}$
}

POLITICAL INTERVENTION IN THE LEGAL SENTENCE? THE CULTURAL BASES OF THE MINIMUM PENALTY

¿INTERVENCIÓN POLÍTICA EM LA SENTENCIA DEL DERECHO? LOS FUNDAMENTOS CULTURALES DE LA PENA MÍNIMA

Maíra Rocha Machado²

Álvaro P. Pires ${ }^{3}$

1 Agradecemos a três organismos financiadores: o Conselho de pesquisa em ciências humanas do Canadá, o Projeto Pensando o Direito (Ministério da Justiça do Brasil e PNUD - Programa das Nações Unidas para o Desenvolvimento). As ideias expressas aqui não representam o ponto de vista dessas organizações. Agradecemos muito especialmente a nossos dois assistentes de pesquisa, Carolina Cutrupi Ferreira e Pedro Mesquita Schaffa. Agradecemos aos comentários extremamente úteis dos pareceristas anônimos que avaliaram este artigo. Este texto foi publicado em 2010 na revista Criminologie, número 43, n² 2, p. 89-126. A tradução de João Ignácio Coelho Mendes Neto foi financiada pela FGV Direito SP, instituição à qual também dirigimos nossos mais sinceros agradecimentos. A presente versão foi ajustada e complementada a partir dos comentários oferecidos pelos pareceristas anônimos desta revista, aos quais também agradecemos imensamente.

2 Maira Rocha Machado é doutora em direito pela Universidade de São Paulo e professora da FGV Direito SP (maira.machado@fgv.br).

3 Alvaro P. Pires é titular da Cátedra Candense de Tradições Jurídicas e Racionalidade Penal da Universidade de Ottawa (alpires@uottawa.ca). 
Resumo: Este texto visa suprir uma lacuna na literatura sobre a "pena mínima". Mais especificamente, este trabalho busca contribuir à reflexão sobre o conceito de pena mínima e sobre os fundamentos culturais desta prática legislativa. As questões centrais que norteiam este texto são as seguintes: (i) como observar e definir as penas mínimas? (ii) Quais são as justificativas que fundam essa prática legislativa de intervenção política na sentença do direito? E ainda, de ordem mais metodológica, (iii) como distinguir empiricamente as justificativas que fundam certa prática social das justificativas que não a fundam? Para responder a essas questões, este texto baseia-se no estudo sistemático da legislação brasileira, canadense e francesa, bem como na literatura disponível sobre o tema.

Palavras-chave: pena mínima legislativa; separação de poderes; teorias da pena; dosimetria; cálculo da pena; fundamentação

Abstract: This text aims to fill a gap in the literature on the "minimum penalty". More specifically, it aims to contribute to reflection on the concept of minimum penalty, and on the cultural bases of this legislative practice. The key questions that guide this text are: (i) how to observe and define the minimum penalties? (ii) What are the justifications that form the basis of this legislative practice of political intervention in the legal sentence? And in a more methodological sense, (iii) how can we empirically distinguish between the justifications that form the basis of a certain social practice and those that do not? To respond to these questions, this text uses systematic study of the Brazilian, Canadian and French legislation, as well as the literature on the theme.

Keywords: minimum legislative penalty; separation of powers; theory of penalty; dosimetry; calculation of the penalty; basis

Resumen: Este texto tiene el propósito de llenar un vacío en la literatura sobre la "pena mínima". Más específicamente, este trabajo quiere contribuir a la reflexión sobre el concepto de pena mínima y sobre los fundamentos culturales de esta práctica legislativa. Las cuestiones centrales que orientan este texto son las siguientes: (i) 
¿cómo observar y definir las penas mínimas? (ii) ¿Cuáles son las justificaciones que fundamentan esa práctica legislativa de intervención política en la sentencia del derecho? Y también, de orden más metodológico, (iii) ¿Cómo distinguir empíricamente las justificaciones que fundamentan cierta práctica social de las justificaciones que no la fundamentan? Para responder a esas cuestiones, este texto se basa en el estudio sistemático de la legislación brasileña, canadiense y francesa, así como en la literatura disponible sobre el tema.

Palabras clave: Pena mínima legislativa; Separación de poderes; Teorías de la pena; Dosimetría; Cálculo de la pena; Fundamentación.

INTRODUÇÃO

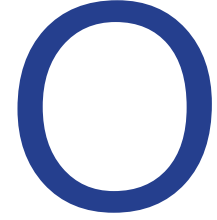

problema do qual parte esta pesquisa é um tipo de enigma no plano político e jurídico. Chamemos de "enigma da intervenção política na sentença do direito". Para apresentá-lo, podemos dizer que, na sociedade contemporânea, reconhece-se frequentemente que o sistema político deve se abster de intervir nas decisões do sistema de direito sobre casos concretos. Uma tal intervenção nos exporia ao risco de ser observada como um sinal de autoritarismo incompatível com os princípios da sociedade democrática. Nesse sentido, a separação de poderes seria não apenas uma situação de fato, mas, também, nos regimes democráticos, um tipo de "princípio prático" a ser protegido e desenvolvido tanto pelas autoridades políticas quanto jurídicas. No entanto, as legislações criminais ocidentais modernas ainda reproduzem, desde os séculos XVIII e XIX, ao menos três modelos de estrutura de penas que parecem "contradizer" este princípio prático da separação de poderes. Esses modelos, como veremos, podem ser observados como uma forma de intervenção do sistema político na sentença do direito e, entre eles, encontramos o modelo da "pena mínima". Ademais, esses modelos são frequentemente utilizados pelo sistema político para orientar ou forçar a sentença do direito em direção à exclusão social dos indivíduos. Isto ocorre diretamente quando esses modelos são construídos com a pena de morte ou de prisão. E a pena de prisão pode ser 
de longa duração (5, 10... 25 anos). Esses modelos de estrutura de penas resistem ao tempo e atravessam até mesmo os períodos "progressistas" de reforma nos quais declaramos a intenção de reduzir o uso da pena de prisão, de abolir a pena de morte ou de fazer evoluir a causa dos direitos humanos. Em poucas palavras, esses modelos têm uma probabilidade pequena de serem abolidos.

O enigma não diz respeito à existência desses modelos, mas sim ao fato de que eles parecem, ainda hoje, fundados e perfeitamente legítimos. Nós não os observamos como reminiscências do passado. Então, neste trabalho, nós buscamos encontrar, da forma mais clara possível, as ideias que permitem a esses modelos, e muito particularmente à pena mínima legislativa, fundar sua existência e resistir ao tempo.

No pano de fundo desse enigma encontramos o início de uma reflexão sobre o problema da determinação das fronteiras entre o sistema político e o sistema de direito criminal. De forma mais específica, o objetivo deste trabalho é contribuir à reflexão, em primeiro lugar, sobre o conceito de pena mínima e, em seguida, sobre os fundamentos culturais desta prática legislativa. Nossas duas questões centrais são, portanto, as seguintes: 1) como observar e definir as penas mínimas? e 2) quais são as justificativas que fundam essa prática legislativa de intervenção política na sentença do direito? Complementa essa última questão uma outra, de ordem mais metodológica: como distinguir empiricamente as justificativas que fundam certa prática social das justificativas que não a fundam?

Esses dois subtemas visam suprir uma lacuna na literatura. Por um lado, não encontramos reflexões suficientemente desenvolvidas sobre o conceito de "pena mínima". Diferentes modelos de estruturas de penas encontram-se, portanto, confundidos. Evidentemente, isso não significa que esses estudos não tenham fornecido observações essenciais para a nossa própria construção conceitual. Por outro lado, esses estudos fizeram múltiplas referências aos motivos invocados para aceitar ou recusar as penas mínimas, mas não concentraram sua atenção sobre os fundamentos dessa prática. Além disso, a questão central da intervenção política na sentença do direito não é tematizada. 
As reflexões que seguem foram extraídas de uma pesquisa empírica sobre a pena mínima em três "jurisdições" ${ }_{4}$ da sociedade-mundo: o Brasil, o Canadá e a França. A pesquisa baseia-se em entrevistas semiestruturadas com juízes e promotores no Brasil e no Canadá, bem como em análise documental da jurisprudência, da literatura e da legislação nos três países. Os resultados globais da pesquisa ainda estão sendo finalizados ${ }^{5}$. Este texto limita-se a apresentar o componente teórico da pesquisa, sobretudo a elaboração conceitual realizada a partir do estudo sistemático da legislação dos três países e da literatura que debruçamos sobre o tema.

\section{A PRÁTICA DA PENA MÍNIMA NO BRASIL, CANADÁ E FRANÇA}

Iniciamos, então, com a apresentação de algumas informações gerais sobre a prática da pena mínima nessas jurisdições que possam ajudar na compreensão dos argumentos expostos aqui.

O Brasil ilustra o caso de uma trajetória estável em relação à pena mínima. As comunicações políticas e jurídicas permaneceram em grande medida indiferentes a qualquer inflexão significativa desta prática desde o século XIX. Não houve sequer um verdadeiro debate sobre essa questão na doutrinajurídica. Ao contrário, encontramos uma valorização extraordinária e crescente da pena mínima até hoje. A pena mínima de prisão é apresentada como uma maneira de exprimir a hierarquia dos valores fundamentais da sociedade. Quanto mais uma norma de

4 O termo "jurisdição", mais do que o termo "país", foi adotado aqui por duas razões principais. A primeira é que ele é muito mais maleável e preciso que o termo "país". Por exemplo, nos Estados Unidos, no interior do próprio país, há várias jurisdições de direito criminal: há uma jurisdição federal e cada Estado tem seu próprio programa legislativo de direito criminal. O termo país é, então, impreciso. A segunda razão é que a sociologia tem renovado sua aparelhagem conceitual para dar conta da sociedade-mundo e para abandonar o que Beck (2000: 13) denomina "nacionalismo metodológico". Isso, obviamente, não impede que levemos em conta as especificidades regionais.

5 Resultados parciais desta pesquisa foram publicados também em Machado, Maira; Pires, Alvaro; Ferreira, Carolina e Schaffa, Pedro. A complexidade do problema e a simplicidade da solução: a questão das penas mínimas. Brasília: Projeto Pensando o Direito MJ/PNUD, vol. 17, 2009. Disponível em: http://pensando.mj.gov.br/wp-content/ uploads/2015/07/17Pensando_Direito3.pdf. Ver, ainda, a ser publicado em breve: Machado, Maira. "Entre a lei e o juiz: os processos decisórios na definição de penas". Revista Brasileira de Ciências Criminais (no prelo). 
comportamento é observada como importante, mais a exclusão social mínima deve ser também. O modelo da pena mínima foi introduzido pelo primeiro Código criminal em 1830. E este modelo ocupará um espaço cada vez maior até o Código penal de 1940. A partir desse momento, ele deixa de ser um dos modelos adotados para se tornar a maneira habitual e absoluta de construir um "tipo penal" (uma incriminação com uma pena correspondente). Hoje é praticamente impossível aumentar o número de penas mínimas na legislação brasileira. Para chegar a esta constatação, nós utilizamos um software, o SISPENAS ${ }^{6}$, que repertoriou os 1688 tipos penais da legislação brasileira (incluindo todas as infrações do Código Penal e da legislação especial) em vigor no mês de agosto de 2009. Deste total, somente 4 tipos penais não têm nenhuma pena mínima de prisão e/ou multa. E 97\% desses tipos têm uma pena mínima de prisão; em apenas 14\% desses casos, o tribunal pode escolher entre uma pena mínima de multa ou de prisão. Com efeito, essa quase-impossibilidade de aumentar o número dessas penas não impede que o legislador aumente seus quantum.

O Canadá ilustra o que podemos chamar de trajetória histórica regressiva. No (primeiro) Código criminal de 1892, havia somente 31 infrações com pena mínima, das quais 6 de prisão e 25 de multa. O modelo de estrutura de penas dominante nesse Código estabelecia (e estabelece ainda) somente uma pena máxima (sem indicação de uma pena mínima). Esse modelo consagra a fórmula seguinte: "quem fizer X pode ser punido por uma pena de prisão de até 2 anos" (e/ou "de multa até $\$ 200,00)^{7}$. Entre as seis infrações com pena mínima de prisão, uma tinha uma pena de cinco anos e duas outras de três anos. Essas três infrações referem-se a furto no serviço dos correios. Uma outra infração tinha uma pena de três meses e as duas últimas de um mês. O Código previa também seis casos de pena de morte, mas esta prática tinha o estatuto de "pena única" (a única sanção possível) somente no caso de homicídio (de primeiro grau). O modelo

6 O SISPENAS é um software das normas de comportamento e de sanção na legislação brasileira em vigor. O programa e o banco de dados foram desenvolvidos pelo Núcleo de Estudos sobre o Crime e a Pena da Escola de Direito da Fundação Getúlio Vargas. Para mais detaIhes sobre esse programa, ver Machado, Marta, Maira Machado e Fábio Andrade. Sispenas: Sistema de consulta sobre crimes, penas e alternativas à prisão. Série Pensando o Direito - Penas Alternativas, no 6, 2009. Disponível em http://pensando.mj.gov.br/wp-content/ uploads/2015/07/06Pensando_Direito3.pdf (último acesso em 24.03.2016).

$7 \quad$ Este modelo aparece também em um projeto de Código Penal no Brasil em 1969. 
de pena mínima estava então presente mas raramente atualizado pelo sistema político. Em uma reforma ocorrida em 1954, o número total de penas mínimas no Código foi reduzido a nove, mas as infrações com pena mínima de prisão passam de seis a oito. Essa mudança é acompanhada de um aumento da utilização da pena de prisão no Código. Em 1892, o Código comportava 50 infrações contendo exclusivamente uma pena de multa (sem prisão); depois da reforma de 1954, todas as infrações passaram a autorizar o recurso à pena de prisão. $O$ número total de penas capitais foi reduzido a cinco, mas o número de "penas únicas" passará de um a dois: a pena de morte torna-se a única pena disponível para duas infrações (homicídio e alta traição). Em 1961, o Canadá cria uma pena mínima de sete anos no quadro das infrações relativas a drogas (importar/exportar). Em 1976, a pena de morte é abolida para todas as infrações do Código. Mas, em troca, será estabelecida uma pena única perpétua para três infrações (alta traição e homicídio de primeiro e segundo graus) e fixado um período de encarceramento mínimo de 25 anos (para a alta traição e o homicídio de primeiro grau) e de 10 anos (para o homicídio de segundo grau) para que seja possível a solicitação da liberdade condicional.

Nós consideramos que é nos anos 1960, e particularmente após a abolição da pena de morte, que o período de regressão se inicia. Naquele momento, ainda há no Canadá uma forte oposição à pena mínima no meio jurídico e entre os especialistas. Até para a Comissão canadense sobre a determinação da pena o discurso de reforma oficial e dominante opõe-se fortemente a esta prática política ${ }^{8}$. Em relação aos hábitos precedentes e expectativas dominantes, haveria então "regressão". Um ano após a abolição da pena de morte, o Parlamento criará outras penas mínimas relativas ao uso de armas de fogo. Em 1999, Gabor e Crutcher estimam em 29 o número de penas mínimas (incluídas as três penas únicas) de prisão no Código ${ }^{9}$. Mais tarde, Raaflaub estima em 40 o número de infrações com penas mínimas de prisão ${ }^{10}$.

8 Commission canadienne sur la détermination de la peine. Réformer la sentence: une approche canadienne. Ottawa: Ministère des Approvisionnements et Services Canada, 1987.

9 GABOR, Thomas; CRUTCHER, Nicole. Les effets des peines minimales obligatoires sur la criminalité, la disparité des peines et les dépenses du système judiciaire. Ottawa: Ministère de la Justice du Canada, 2002, p.1. Disponível em http://www.justice.gc.ca/ fra/pr-rp/sjc-csj/ajc-ccs/rr02_1/rr02_1.pdf (último acesso em 24.03.2016).

10 RAAFLAUB, W. R. Les peines minimales obligatoires. Service d'information et de recherche parlementaires. Canada: Bibliothèque du Parlement, 2006. Disponível em 
A França, por sua vez, ilustra uma trajetória "em pêndulo". O Código Penal de 1810 adotou de forma predominante o modelo da pena mínima; o novo Código Penal de 1992 substituiu amplamente esse modelo (sem eliminá-lo totalmente) pelo modelo da "pena somente máxima"; e uma lei de 2007 do governo conservador de Sarkozy reintroduziu a pena mínima num programa de luta contra a reincidência. A trajetória da França é, portanto, distinta dos dois outros países, o que nos permite relativizar uma série de observações presentes na literatura sobre esse tema.

O caso da França ilustra também a passagem, em um curto período de tempo, de uma prática legislativa centrada no modelo da pena única (Código penal de 1791) a uma prática legislativa centrada quase exclusivamente sobre o modelo da pena mínima e máxima (Código penal de 1810)로. Esta virada muito marcada, em conjunto com o que foi possível observar em relação ao Brasil e ao Canadá, permitiu-nos construir a seguinte hipótese empírica: até que se prove o contrário, o século XIX constitui o "tempo forte"12 da adoção da prática da pena mínima no Ocidente. No século XIX, três modelos de estrutura de penas vão se opor à pena única: o modelo da pena bipartida ou tripartida; o modelo da pena mínima (associada a uma pena máxima); e o modelo da pena máxima somente (sem pena mínima).

Ademais, a França adotou, desde o século XIX, uma política legislativa que não busca eliminar totalmente o poder discricionário dos juízes no tocante à pena mínima. A autoridade política francesa progressivamente aprendeu a reconhecer a importância de certa margem de manobra em matéria de penas para o respeito aos princípios do sistema de direito. E o retorno à pena mínima não a eliminou

http://www.bdp.parl.gc.ca/content/lop/researchpublications/prb0553-f.htm (último acesso em 24.03.2016). Nos Estados Unidos, a jurisdição federal parece ter percorrido uma trajetória regressiva semelhante. Brinkley indica que "o maior aumento no uso federal dessas penas produziu-se num número relativamente pequeno de dispositivos, tendo sua grande maioria sido instituída após 1984": Brinkley, L. V. (2003). Preface. In L. V. Brinkley (Ed.), Mandatory Minimum Sentencing: Overview and Background. New York: Novinka Books.

11 Por exemplo, o artigo 320 conserva o modelo da pena única (pena de morte) para o homicídio doloso, o parricídio, o infanticídio e o envenenamento.

12 Este conceito é de Michel Foucault: FOUCAULT, Michel. La poussière et le nuage. In: FOUCAULT, Michel, Dits et écrits 1954-1988, edition de 1994. Paris: Éditions Gallimard, 1980 , p. 30. 
totalmente. Esta característica do caso francês, que contrasta com o caso do Brasil e do Canadá nos será particularmente útil no plano conceitual.

Enfim, resta-nos precisar, pela negativa, que nosso objetivo não é tratar de um eventual "retorno" à pena mínima ou explicar o que ocorre especificamente a partir da segunda metade do século XX. Não é tampouco examinar a questão da eficácia/ineficácia da pena mínima em relação ao controle da criminalidade ${ }^{13}$. Estes dois tipos de estudo nos distanciam de nosso objeto.

Nós trataremos inicialmente do problema da conceitualização e, em seguida, do problema dos fundamentos da prática. Esperamos poder compreender melhor as razões pelas quais essa prática tem mais chances de se reproduzir e de ser atualizada do que de ser abolida, em que pesem as repetitivas reivindicações nesse sentido.

\section{PROBLEMAS DE OBSERVAÇÃO E DE CONCEITUALIZAÇÃO DA PENA MÍNIMA}

Nós identificamos na literatura cinco dificuldades importantes na observação da pena mínima. Três são de ordem conceitual e duas dizem respeito ao alvo do observador. Mas antes apresentaremos os quatro modelos de estruturas de penas ${ }^{14}$. Estes modelos existem tanto no common law quanto na tradição

13 Em relação a este ponto, Tonry é categórico, "penas mínimas não funcionam": TONRY, Michael. Mandatory Penalties. In: TONRY, Michael (ed.), Crime and Justice: A Review of Research. Chicago: University of Chicago Press, 1992, v. 16, p. 243. Roberts constata também que "os estudos que se debruçaram sobre a incidência dessas leis [estabelecendo penas mínimas] [não] revelam qualquer efeito sobre as taxas de criminalidade": ROBERTS, Julian. Peines d'emprisonnement obligatoires dans les pays de common law: quelques modèles représentatifs. Ottawa: Ministère de la Justice du Canada, 2005, p. 2. Disponível em http://www.justice. gc.ca/fra/pr-rp/sjc-csj/ajc-ccs/rr05_10/rr05_10.pdf (último acesso 24.03.2016). Ver também: DOOB, Anthony N.; CESARONI, Carla. The Political Attractiveness of Mandatory Minimum Sentences. Osgoode Hall Law Journal, 2001, 39 (2 \& 3), p. 287-304; também sobre o tema: GABOR, Thomas; CRUTCHER, Nicole. Les effets des peines minimales obligatoires sur la criminalité, la disparité des peines et les dépenses du système judiciaire, 2002. Sobre o problema mais geral da crença na efetividade da severidade, ver Doob e Webster: DOOB, Anthony N.; WEBSTER, Cheryl Marie. Sentence Severity and Crime: Accepting the Null Hypothesis. Crime and Justice: A Review of Research, 2003, 30, p. 143-195.

14 Estes modelos podem ser observados também em Doyle: DOYLE, Charles. Federal Mandatory Minimum Sentencing Statutes: A List of Citations with Captions, Introductory Comments, and Bibliography. In: BRINKLEY, L. V. (ed.). Mandatory Minimum Sentencing: Overview and Background. New York: Novinka Books, 2003, p. 49-51. 
romano-germânica. De acordo com a nossa linguagem conceitual, os modelos são os seguintes:

1. O modelo da pena única ${ }^{15}$.

Exemplo: "Quem fizer $x$ deve ser condenado à prisão perpétua".

2. O modelo da pena bipartida ou tripartida.

Exemplo: "Quem fizer $x$ deve ser condenado à morte ou à prisão perpétua".

3. O modelo da pena mínima (combinada quase sempre a uma pena máxima) ${ }^{16}$.

Exemplo 1: "Quem fizer $x$ deve ser condenado à pena de prisão de ao menos 3 anos [e até 7 anos].

Exemplo 2: "Quem for condenado a uma pena de prisão não poderá ser liberado condicionalmente antes de ter cumprido ao menos $1 / 3$ de sua pena"

4. O modelo da pena somente-máxima (sem pena mínima).

Exemplo: "Quem fizer $x$ pode ser condenado a uma pena de prisão de até 5 anos.

Somente os três primeiros modelos colocam o problema da intervenção política na sentença do direito. Com efeito, o quarto modelo não intervém no mesmo sentido dos anteriores: ele estabelece apenas um limite político máximo à intervenção do sistema de direito criminal. Como veremos, o modelo da pena mínima é o mais complexo e se apresenta sob formas mais ou menos rígidas de intervenção política. Passemos agora aos cinco problemas identificados na literatura.

i. Uma ausência de distinção conceitual entre pena única e pena mínima. O conceito de pena mínima é empregado para designar as duas situações.

15 Em inglês: "single sentence statute, flat sentencing or flat punishment".

16 Em inglês: "minimum sentencing or minimum punishment". Também se faz referência a elas por meio da expressão "not-less-than category". Na França, utiliza-se frequentemente a expressão "pena chão" (peine plancher). 
ii. Uma ausência de distinção conceitual entre a pena mínima e a pena bipartida ou tripartida. O conceito de pena mínima é empregado para designar também essa situação.

iii. Uma tendência a restringir o conceito de pena mínima legislativa à sentença pronunciada pelo tribunal. A pena mínima legislativa que se dirige ao juiz de aplicação de penas ou às autoridades correcionais e carcerárias fica completamente fora do campo de visão ("blind spot").

iv. Uma tendência a focalizar a observação somente sobre a pena mínima que é construída com a pena de prisão.

v. Uma tendência a problematizar somente uma das modalidades da pena mínima: aquela que não deixa qualquer espaço decisório ao tribunal (a "pena mínima absoluta"). As outras modalidades ficam então em um "ponto cego" ("blind spot") da observação.

Para reduzir a exposição, trataremos dos dois primeiros problemas conjuntamente. Tornou-se uma espécie de lugar-comum na literatura não distinguir a pena mínima nem da pena única nem da pena bipartida (ou tripartida). A ausência dessa distinção produz descrições imprecisas e nos leva também a perder de vista a novidade histórica da pena mínima em relação à pena única e às outras estratégias possíveis de formulação de normas de sanção (modelo 4). A confusão com a pena única leva alguns pesquisadores até mesmo a ver a "pena mínima criminal" numa época em que a legislação ainda não se auto-diferenciava como legislação criminal.

Assim, por exemplo, Gabor e Crutcher escrevem: "Dizem que a pena mínima é tão antiga quanto a própria civilização ${ }^{17}$. $\mathrm{O}$ texto bíblico da lex talionis - olho por olho, dente por dente - era uma punição obrigatória que deixava pouca margem para o perdão ou para uma redução da pena". Com esse tipo de observação, os autores entram rapidamente em contradição. De fato, na frase seguinte, eles escrevem: "Nos Estados Unidos, as penas mínimas obrigatórias remontam a 1790

17 GABOR, Thomas; CRUTCHER, Nicole. Les effets des peines minimales obligatoires sur la criminalité, la disparité des peines et les dépenses du système judiciaire, 2002, p. 1. 
e, desde 1950, elas suscitam muita ambivalência". Brinkley também funde os dois modelos de penas e acrescenta que as "penas mínimas obrigatórias no nível federal existem [nos Estados Unidos] desde 1790 [...]" ${ }^{\prime 18}$. Não sabemos então se ele já se refere ao modelo da pena mínima "não menos que" ou ao modelo da "pena única".

No Canadá, a posição tomada pela Comissão canadense sobre a determinação da pena é mais complexa e difícil de interpretar. A Comissão inicialmente também falou em "duas categorias de penas mínimas" referindo-se às penas única (modelo 1 ) e mínima (modelo 3). Mas ela não manteve essa terminologia. Ela empregou quase imediatamente a distinção entre "prisão perpétua obrigatória/ penas mínimas obrigatórias" ${ }^{19}$. Ora, essa distinção diferencia pena única e pena mínima. E ela dirá que as "penas mínimas normais" "são definidas pela expressão 'ao menos' ou por uma expressão equivalente" ${ }^{20}$. Com essa distinção, a definição torna-se mais precisa que aquela dada por muitos outros autores.

Na realidade, a pena única é o modo mais rudimentar e "invasivo" de intervir politicamente pela legislação na sentença do direito. Ela não conhece "mais" nem "menos". E ela também não conhece "ou". Ela não atribui qualquer autonomia decisória ao sistema de direito criminal. A sobrevivência dessas penas no século XXI constitui assim um "mistério sociológico". Como esse modelo pode ser aceito por tanto tempo e percebido como legítimo, inclusive pelo próprio sistema de direito criminal?

O modelo da pena bipartida, que não examinaremos em detalhe aqui, é ligeiramente menos restritivo do que o modelo da pena única: ele "oferece" duas sanções, sem modulação de quantidade, ao sistema de direito. No século XX, tratava-se frequentemente de uma alternativa: pena de morte ou pena perpétua. Este modelo parece ser um tipo de modelo intermediário ou de transição entre a pena única e a pena mínima.

18 BRINKLEY, L. V. Preface. In: Brinkley, L. V. (Ed.), Mandatory Minimum Sentencing: Overview and Background. New York: Novinka Books, 2003, vii.

19 Commission canadienne sur la détermination de la peine. Réformer la sentence: une approche canadienne. Ottawa: Ministère des Approvisionnements et Services Canada, $1987,194$.

20 Commission canadienne sur la détermination de la peine. Réformer la sentence: une approche canadienne. Ottawa: Ministère des Approvisionnements et Services Canada, 1987, 193. 
A terceira dificuldade conceitual diz respeito à autoridade destinatária da pena mínima legislativa. O problema aqui decorre da localização da pena mínima no processo penal (considerado do início ao fim): alguns observadores não viram os dispositivos legislativos que se dirigem às autoridades correcionais (carcerárias) ou aos juízes de atuam na fase do cumprimento da pena como sendo penas mínimas. Ora, com a complexificação do sistema de direito criminal a partir do século XIX, o número de autoridades que se tornaram destinatários potenciais da pena mínima multiplicou-se. Em poucas palavras, o que acontece aqui?

Duas mudanças estreitamente ligadas e muito importantes acontecem nas últimas décadas do século XVIII e nas primeiras do século XIX. De um lado, a prisão afirma-se como o "protótipo" da penalidade em direito criminal ${ }^{21}$. De outro lado, ocorre uma alteração cultural no registro de observação do "sofrimento" que a pena criminal deve infligir e exprimir. Inspirando-nos num conceito de Norbert Elias ${ }^{22}$, que assumiu a forma de um neologismo, diremos que Beccaria exprime de modo preciso um mecanismo cognitivo ou cultural que denominaremos a "temporação do sofrimento-severidade" em relação às sanções. Temporação significa aqui "pôr na dimensão temporal", estabelecer uma relação com o tempo ${ }^{23}$.O "sofrimento" que a pena deve infligir ao criminoso recairá cada vez menos sobre o corpo e cada vez mais sobre a dimensão temporal. De acordo com esse mecanismo, a pena, para fazer sofrer o culpado de uma maneira aceitável, deve "simplesmente" se prolongar no tempo.

A pena (de prisão) cuja severidade se exprime na dimensão temporal pode agora ser observada como "humanista" e mesmo se ela se traduz, para o culpado, em um longo período de encarceramento e se ela o mantém na prisão somente para fazê-lo sofrer ou para fazê-lo "pagar seu crime" (sem que ele represente um risco particular para os outros). Formulamos então a hipótese de que esse

21 FOUCAULT, Michel. Surveiller et punir: naissance de la prison. Paris: Éditions Gallimard, 1975 e LASCOUMES, P. ; PONCELA, P.; LENOËL, P. Au nom de I'ordre: une histoire politique du code pénal. Paris: Hachette, 1989

22 Elias, N. (1984). Du temps. Paris: Fayard, 1997, p. 82.

23 PIRES, Alvaro P.; GARCIA, Margarida. Les relations entre les idées: droits de la personne et théories de la peine face à la peine de mort. In: CARTUYVELS, Y; DUMONT, $H$; OST, F.; KERCHOVE, M. van de; DROOGHENBROECK, S. Van (eds.). Les droits de I'homme, bouclier ou épée du droit pénal? Bruxelles: Bruylant et Facultés universitaires Saint Louis, 2007, p. 291-336. 
mecanismo dará as condições de possibilidade e facilitará enormemente a implementação das tarifas inflacionistas que conhecemos ainda hoje $(10,15$, 20, 25, 30 anos), particularmente para os crimes considerados graves. Assim, a gestão da pena de longa duração apresenta-se como um novo problema e a relação entre a teoria da reabilitação e as outras duas teorias da pena (retribuição e dissuasão) estabelecerá um patamar mínimo de tempo: mesmo "reabilitado", ele deverá esperar na prisão para pagar por seu crime, para dissuadir os outros, para exprimir a reprovação social. Nasce então, com as diferentes formas de liberdade condicional e de gestão dos regimes carcerários, a pena mínima após o pronunciamento da pena pelo tribunal, aquela que se dirige aos "novos decisores": juízes de gestão de penas, diretores de penitenciárias, etc.

Essa pena mínima exprime-se também geralmente pela mesma fórmula "ao menos" (ou equivalente). Diremos, por exemplo, que um detento não pode ser liberado antes de ter cumprido ao menos $1 / 3$ de sua pena. No Canadá, nos casos de alta traição e de homicídio em primeiro grau, a lei estipula que "o benefício da liberdade condicional está subordinado [...] ao cumprimento de ao menos vinte e cinco anos da pena" (art. 745 do Código Penal; grifo nosso).

Esse tipo de pena mínima, que é frequentemente esquecido, não passou despercebido pela Comissão de Reforma do Direito do Canadá24: "Às vezes, também falamos em pena mínima para significar a parte de uma pena de prisão que deverá necessariamente ser cumprida no meio carcerário". Lembremos que a Comissão considera que "é difícil ver por que deve haver um período mínimo de tempo a ser cumprido em detenção completa"25.

A quarta dificuldade não é de ordem conceitual, mas ela ilustra o fato de os observadores dificilmente se aterem à própria pena mínima. Seremos breves nesse ponto. Os observadores invocam a pena mínima, mas seus interesses rapidamente se orientam em direção às penas mínimas de prisão ${ }^{26}$. De fato, 24 Commission de réforme du droit du Canada. Imprisonment and Release. Working Paper 11. In: Commission de réforme du droit du Canada (Ed.), Studies on imprisonment (1-46).

Ottawa: Minister of Supply and Services Canada, 1976, p. 26.

25 É nossa tradução pois essa passagem é mais clara na versão inglesa (p. 24) do relatório: "[...] it is difficult to see why there should be a minimum time to be served in complete custody".

26 Ver, por exemplo, o estudo de Crutcher sobre as penas mínimas de prisão no Canadá a partir do Código criminal de 1892: Crutcher, N. (2001). The Legislative History of Mandatory Minimum Penalties of Imprisonment in Canada. Osgoode Hall Law Journal, 39 (2 \& 3), 273-285. 
estamos convencidos que uma das principais consequências da pena mínima legislativa consiste na reprodução da sanção de encarceramento. Afinal, a pena mínima está ligada a essa sanção de modo persistente, particularmente para os crimes considerados mais graves. Todavia, as ideias que fundam a pena mínima legislativa são as mesmas qualquer que seja o tipo de sanção. Se o observador quiser ir à raiz do problema, ele não pode deixar sua atenção concentrar-se exclusivamente num tipo de sanção. Também é preciso dizer que, mesmo do ponto de vista pragmático, as penas mínimas não prisionais podem ser um problema para o tribunal e conduzir ao encarceramento ${ }^{27}$.

A quinta dificuldade é de outro tipo. Alguns observadores indicaram, com razão, que o modelo da pena mínima legislativa pode ser construído com diferentes graus de fechamento/abertura ao arbítrio judiciário ${ }^{28}$. Nós vamos propor duas distinções, situadas em dois planos, para observar esses diferentes graus. O quadro a seguir busca representar essas duas distinções.

QUADRO 1

Graus de abertura/fechamento da pena mínima legislativa ao arbítrio das autorida des do sistema de direito

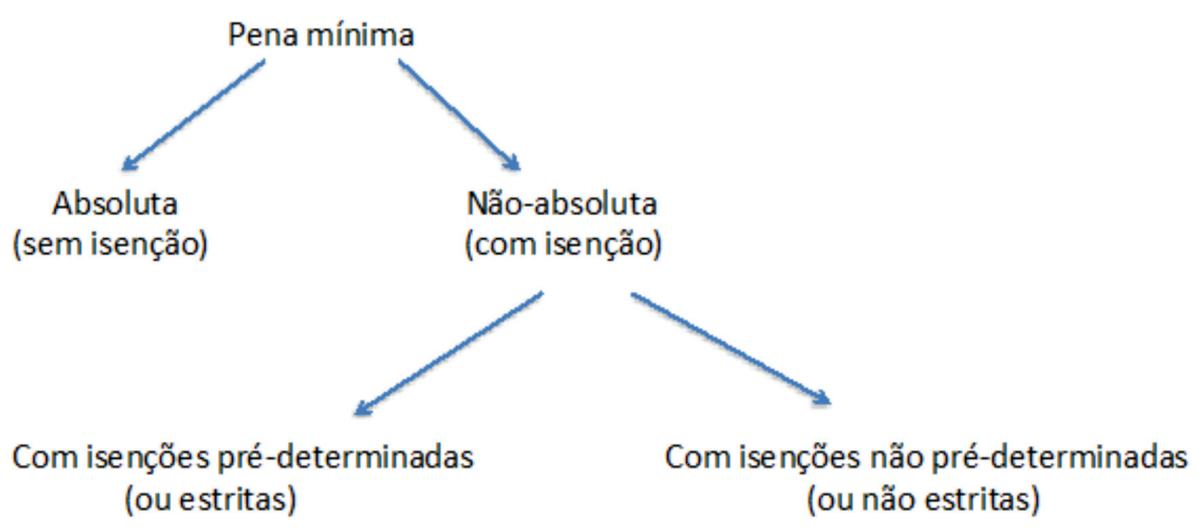

27 Ver, por exemplo, o caso R. C. Wu, 2003 SCC 73, [2003] 3 S.C.R. 530.

28 Sobre o assunto, ver: DOYLE, Charles. Federal Mandatory Minimum Sentencing Statutes: An Overview of Legislation. In: BRINKLEY, L. V. Brinkley (ed.), Mandatory Minimum Sentencing: Overview and Background. New York: Novinka Books, 2003, p. 33-38. ROBERTS, Julian. Peines d'emprisonnement obligatoires dans les pays de common law: quelques modèles représentatifs, 2005, p. 2. 
A primeira distinção é entre pena mínima absoluta/não absoluta. Há leis que proíbem toda forma de isenção à pena mínima: os tribunais não podem deixar de aplicar a pena mínima em nenhum caso que responda às características legais. Como indica Roberts, "atualmente, os juízes não se beneficiam de nenhum poder discricionário para reduzir a pena de alguém que foi considerado culpado de uma infração submetida a uma pena mínima obrigatória no Canadá" 29. Mas há, por outro lado, leis que estabelecem uma "válvula de segurança"30 que permite aos decisores subtrair certos casos da aplicação da pena mínima. É neste plano que intervém a segunda distinção. Essa válvula de segurança pode adotar, por sua vez, dois graus de abertura. Às vezes, as condições para a isenção são estritamente estipuladas pela lei. Não há qualquer margem de manobra para considerar outros elementos não previstos pelo legislador. Por exemplo, a lei autoriza o tribunal a excluir da pena mínima um indivíduo que recebe sua primeira condenação. Do outro lado da segunda distinção, a lei não somente permite isenções, mas ela também deixa ao tribunal a possibilidade de indicar livremente as razões da isenção. Nos dois casos, o tribunal deve geralmente motivar a isenção. Roberts indica que, na Inglaterra e no País de Gales, por exemplo, os tribunais gozam de uma certa flexibilidade para não aplicar a pena mínima prevista pela lei ${ }^{31}$.

Primeira pergunta: como devemos designar essas penas mínimas com diferentes graus de abertura à discricionariedade judiciária? A literatura emprega frequentemente as distinções entre pena mínima obrigatória/presumida ou pena mínima obrigatória/menos obrigatória. Não vamos adotá-las. Propomos substituílas pela distinção pena mínima absoluta/não absoluta. A distinção "pena mínima com/sem válvula de segurança" também é aceitável à condição de eliminar o adjetivo "obrigatória". Nós diremos também que as penas não absolutas podem 29 ROBERTS, Julian. Peines d'emprisonnement obligatoires dans les pays de common law: quelques modèles représentatifs, 2005, p. 9.

30 Doyle exprime essa ideia do seguinte modo: "A few are somewhat less mandatory than others" (grifo nosso). Essa formulação nos parece inadequada. Mas ele também utiliza a distinção "with/without a safety valve". Essa última formulação nos parece plenamente aceitável. DOYLE, Charles. Federal Mandatory Minimum Sentencing Statutes: An Overview of Legislation. In: BRINKLEY, L. V. Brinkley (ed.), Mandatory Minimum Sentencing: Overview and Background. New York: Novinka Books, 2003, p. 34.

31 ROBERTS, Julian. Peines d'emprisonnement obligatoires dans les pays de common law: quelques modèles représentatifs, 2005, p.14-15. 
autorizar isenções estritas e não estritas. No Canadá e no Brasil, todas as penas mínimas são absolutas.

Segunda pergunta: por que abandonar o conceito de pena mínima obrigatória (mandatory minimum punishment) utilizado frequentemente? Porque achamos essa linguagem imprecisa e inapropriada do ponto de vista teórico. Por um lado, a distinção obrigatória/não obrigatória é imprecisa, porque a pena mínima é sempre plenamente obrigatória para os casos que ela inclui. A diferença entre a pena mínima absoluta e não absoluta não reside no seu caráter mais ou menos obrigatório, mas na extensão que a lei dá à obrigação: num caso ela aceita isenções e, no outro, não. É como a diferença entre um autoritarismo e um autoritarismo esclarecido. Por outro lado, a distinção obrigatória/menos obrigatória (ou obrigatória/presumida) suscita uma ilusão do ponto de vista da reflexão científica. Ela leva certos pesquisadores, com um enfoque preferencial dirigido para as reformas, a se oporem às penas mínimas (absolutas) mas, ao mesmo tempo, a propor a título de alternativa não a pena somente-máxima (modelo 4), mas penas mínimas não absolutas. É verdade que a pressão política sobre a sentença do direito é menor quando a pena mínima é não absoluta. Mas, do ponto de vista das consequências efetivas e virtuais sobre as estruturas do sistema de direito, tanto as penas mínimas absolutas quanto as não absolutas reconduzem às mesmas ideias e às teorias fundadoras dessa prática. Deste ponto de vista, não há diferença significativa entre elas.

O quadro 2 resume o que vimos sobre os três modelos de estrutura de penas representando uma intervenção política na sentença do direito. Ilustra também, a partir do caso canadense, como as legislações contemporâneas combinam uma pena única dirigida ao juiz do processo com uma pena mínima dirigida à autoridade encarregada da gestão das penas. A pena única é ilustrada tendo em conta somente duas opções: a pena perpétua e a pena de morte (onde ela ainda existe). Com a abolição da pena de morte no Canadá em 1976, as três penas únicas restantes estabelecem a prisão perpétua. 
QUADRO 2

Três modelos de estrutura de penas que intervém na sentença do direito

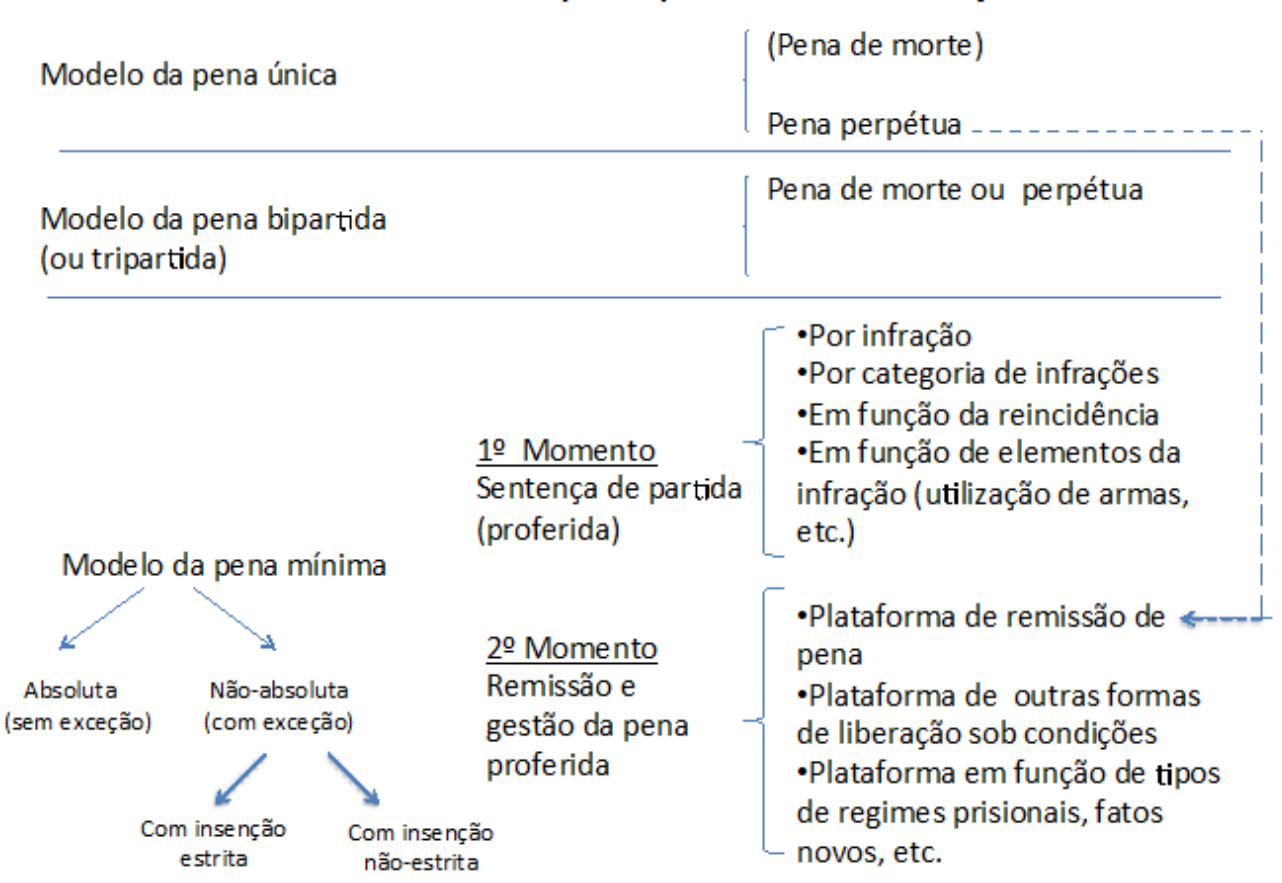

\section{OS FUNDAMENTOS DA PENA MÍNIMA LEGISLATIVA}

Voltemo-nos agora para o problema dos fundamentos da prática legislativa da pena mínima. Sublinhemos, de início, que os fundamentos dessa prática se aplicam também à pena única (modelo 1 ) e à pena bipartida ou à tripartida (modelo 2). Este problema pode ser formulado assim: como viemos a fundar o modelo da pena mínima de modo recorrente desde (ao menos) o século XIX em diversas jurisdições ocidentais?

Comecemos pelas dificuldades que a resposta a esta questão coloca. Encontramos hoje na literatura (mas também nos debates parlamentares e na jurisprudência) um arsenal de argumentos para justificar uma posição favorável ou desfavorável a esta prática legislativa da pena mínima. Eles são ao mesmo tempo argumentos, ideias e justificativas. Esses argumentos apresentam-se como justificativas na medida em que eles se apoiam sobre uma tomada de posição a favor/contra essa prática. Chamemos a totalidade desses argumentos de "um debate de política criminal". 
Para dar uma visão rápida do conjunto da situação, retomemos as observações de Cavanagh e Teasely ${ }^{32}$. Esses autores organizaram esses argumentos ao redor de cinco questões: "A pena mínima (1) ajuda a dissuadir do crime? (2) substitui o poder discricionário do juiz pelo da promotoria? (3) elimina a disparidade injustificada? (4) leva a sentenças inapropriadas para as minorias? e (5) contribui para a superpopulação carcerária?". Evidentemente, essas perguntas não esgotam todo o debate. Por exemplo, Dumont mostrou que é possível opor-se a essa prática a partir de uma perspectiva feminista (que é frequentemente utilizada, paradoxalmente, para aprová-la). ${ }^{33}$

O primeiro debate se desenvolve ao redor de um efeito eventual que é, ao mesmo tempo, uma finalidade oficial e explicitamente buscada por essa prática: uma justificativa e um estímulo para colocá-la para funcionar. A segunda questão diz respeito a um efeito eventual não almejado nas jurisdições nas quais a promotoria dispõe de um grande poder discricionário (para denunciar ou não e para selecionar ou modificar as infrações que integrarão a acusação). A terceira questão examina a utilidade/inutilidade (ou a pertinência/ impertinência) desta prática para favorecer um tipo de política da igualdade perante a lei, mesmo quando este efeito não faz parte dos objetivos políticos explicitamente buscados. As duas últimas questões são semelhantes à segunda: elas buscam saber se essa prática produz efeitos eventuais não (diretamente) desejados. É claro que a pena mínima de prisão não pode contribuir logicamente à redução da população carcerária, mas o eventual aumento (mais ou menos acentuado) desta população não é nem uma finalidade dessa prática nem uma razão para justificá-la.

Ao examinarmos mais de perto o conteúdo desse debate (a favor/contra a pena mínima), vemos que os argumentos não se situam todos em um mesmo plano. Alguns dizem respeito a uma justificativa oficialmente e regularmente dada, nos mais diversos lugares, em favor dessa prática (o efeito dissuasório e a igualdade perante a lei); outros referem-se aos efeitos ou aos fatos não

32 Cavanagh, Suzanne; Teasely, David. Mandatory Minimum Sentencing for Federal Crimes: Overview and Analysis. In: BRINKLEY, L. V. (ed.). Mandatory Minimum Sentencing: Overview and Background (1-31). New York: Novinka Books, 2003, p. 7-19.

33 Dumont, H. Désarmons les Canadiens et armons-nous de tolérance: Bannir les armes à feu, bannir les peines minimales dans le contrôle de la criminalité violente, procès sur une contradiction apparente. Criminal Law Review, 1997, 2 (43). 
diretamente desejados pela prática, mesmo se eles são às vezes implicitamente aceitos (ao menos até um certo ponto). Aqui, vemos se desenhar uma distinção entre os argumentos que se dirigem às justificativas oficiais consideradas aceitáveis e os argumentos que indicam fatos ou efeitos não desejados (e alguns potencialmente inaceitáveis).

Além disso, é fácil imaginar que certos argumentos (ou estudos) sobre os efeitos não desejados podem indicar efeitos que são muito graves (aumento brutal da população carcerária, "sobre-representação" dos pobres nas prisões, etc.). Esses fatos empíricos podem então justificar um questionamento radical da pena mínima. Não devemos, portanto, confundir o caráter mais ou menos convincente dos argumentos com aquilo a que eles se referem. Quando queremos examinar os fundamentos de uma prática, é necessário fazer uma distinção entre os argumentos que se apoiam exclusivamente sobre certos efeitos não desejados e as teorias ou os princípios que fundam a prática. E ainda mais porque os "fundamentos" têm, eles também, seus próprios efeitos não desejados. A pesquisa dos fundamentos exige que prestemos uma atenção especial (Husserl) justamente sobre aquilo que nós queremos fazer, sobre como nós queremos fazer e sobre as teorias que nós construímos e mobilizamos para dar suporte àquilo que fazemos. Vamos reter um ensinamento da sociologia fenomenológica: o "mundo das ideias" (ou do conhecimento) é composto de diferentes camadas de sedimentação ${ }^{34}$. As ideias não estão todas distribuídas num mesmo plano; e elas não têm todas, por assim dizer, o mesmo "peso" ou a mesma "densidade".

De um ponto de vista sociológico, a questão de ordem metodológica passa a ser então: como encontrar, empiricamente, as teorias, os princípios e as ideias que vão desempenhar o papel de um fundamento?

Para responder a esta pergunta, faremos um longo percurso com a ajuda de Lalande $^{35}$ e Boisse ${ }^{36}$. Na verdade, nós adotamos e adaptamos uma distinção que a filosofia faz em certas ocasiões entre um fundamento e as outras justificativas 34 SCHUTZ, A.; LUCKMANN, T. The Structures of the Life-World. Evanston: Northwestern University Press, 1973, v. I, cap. 3.

35 LALANDE, A. Fondement. In: LALANDE, A (Ed.), Vocabulaire technique et critique de la philosophie. Paris: Presses Universitaires de France, 1968, p. 364-366.

36 BOISSE, L. Commentaire critique au mot fondement. In: LALANDE, A (Ed.), Vocabulaire technique et critique de la philosophie (366-367). Paris: Presses Universitaires de France, 1968, p. 366-367. 
possíveis. Tomando emprestado um termo de Boisse, nós vamos qualificar este conjunto de outras justificações possíveis - que são usualmente aquelas centradas sobre as consequências não desejadas - de "fatos justificativos" (a favor ou contra uma prática). Para facilitar a compreensão de nossa exposição, vamos listar desde já os critérios que adotamos para operacionalizar essa distinção entre fundamentos /fatos justificativos:

\section{QUADRO 3}

Critérios operacionais para distinguir dois tipos de justificativas

\section{Os fundamentos}

1. O argumento é auto-suficiente e faz referência diretamente às ideias que repetitivamente sustentam a razâo de ser de uma prática social institucionalizada.

2. O argumento oferece um ponto de apoio para o assentimento e induz, em regra geral, um forte valor de aprovaçâo.

3. O argumento é contemporâneo à prática (têm a mesma longevídade)

4. O argumento é aplicável em todos os lugares onde a prática existe (năo regional?

5. O argumento se aplica com a mesma pertinência a todias as modialidades (variedades) da prática em questăo.

\section{Os fatos justificativos}

1. $\mathrm{O}$ argumento nã̃o é auto-suficiente e não faz referència diretamente às ideias que repetitivamente sustentam a razăo de ser de uma prática sacial institucianalizada ¿mas faz referência a outros estados-de coisa a conhece: conscquências, opiniỗcs, etc.).

2. O argumento häu aferece um ponto de apoio para o assentimento e nāo induz. em regra geral, um forte valor de aprovaçāo.

3. $O$ argumento näu é tontemproråneo à prática (năo têm a mesma longevidade) e não tem um alcance retroativo.

4. O argumento não é aplicável em todos os lugarcs onde a prática cxistc (regional\}

5. O argumento nã̃o se aplica com a mesma pertinência a todas as modalidades (variedades) da prática em questäo.

Para começar, a ideia de fundamento reenvia à ideia de autossuficiência. Ela é uma "metáfora tirada da arquitetura: aquilo sobre o que repousa certa ordem ou certo conjunto de conhecimentos" ${ }^{\prime 37}$. Adaptemos esta metáfora ao nosso problema: o fundamento será dado pelas ideias que se apresentam como os "últimos pontos de apoio" de uma prática, sobre o que ela repousa. E excluamos imediatamente, com Lalande, um dos sentidos possíveis da palavra "repousar": não se trata aqui de repousar no sentido de um ponto de partida lógico ("fundamento da indução"), mas de repousar no sentido de "aquilo que dá a algo [...] sua razão

37 LALANDE, A. Fondement. In: LALANDE, A (Ed.), Vocabulaire technique et critique de la philosophie. Paris: Presses Universitaires de France, 1968, p. 364. 
de $\operatorname{ser}^{\prime 38}$. Podemos dizer também: seu "embasamento teórico"39, no sentido de uma "teoria prática"40. Logo, fundar é "estabelecer uma base sólida", estável e refletida no plano das justificativas, pelo menos até o momento em que essa fundação seja questionada, o que dará ensejo a uma reconstrução das práticas sobre outros fundamentos ou teorias práticas.

Desse modo, quando afirmamos categoricamente que "a pena mínima protege a sociedade" (teoria da dissuasão), seja isto verdadeiro ou falso, nós damos um fundamento a essa prática: nada mais precisa ser acrescentado. $\mathrm{O}$ argumento se sustenta por si só. O mesmo acontece quando dizemos que "a pena mínima é justa porque ela retribui o mal moral do crime por um sofrimento proporcional a esse mal". Seja este um raciocínio distorcido ou não, pouco importa: aqui também, se aceitamos essa concepção de justiça, nada mais precisa ser dito. É claro que, se a pena é considerada "muito elevada" pelo sistema de direito, é aquela pena específica que poderá ser invalidada, mas não as ideias que sustentam a prática (por exemplo, a concepção retributivista da justiça criminal). Isso só pode acontecer se as teorias da retribuição e da dissuasão, na qualidade de fundamentos, forem descreditadas ou substituídas por outras teorias práticas que veiculam outra concepção da justiça criminal. E se as ideias não são abandonadas ou reconstruídas de outro modo, a prática em seu conjunto permanece protegida. Lembremos, contudo, que não é necessário abandonar as ideias fundadoras de uma prática para poder abandoná-la inteira e definitivamente. Podemos abandonar definitivamente a pena de morte e a pena perpétua sem abandonar as ideias que as fundaram.

Por outro lado, se constatamos que "a pena mínima é aceita pelo público ou pelo eleitorado", fica claro que este fato justificativo não é suficiente para fundar a prática. Somos conduzidos a colocar outras questões, tais como, entre outras: por qual razão o público aceitou essa prática? E por qual razão (política? jurídica?) devemos levar em consideração a opinião do público para decidir como punir?

38 LALANDE, A. Fondement. In: LALANDE, A (Ed.). Vocabulaire technique et critique de la philosophie, 1968, p. 364.

39 BOISSE, L. Commentaire critique au mot fondement. In: LALANDE, A (Ed.). Vocabulaire technique et critique de la philosophie, 1968, p. 366-367.

40 Durkheim, Émile. Éducation et sociologie. Paris: Presses Universitaires de France, 2006, cap. 2. 
público pode ter interiorizado as ideias da teoria da dissuasão e pensar que ele estará mais protegido por essa prática. Temos aqui uma indicação de que o argumento oferece uma justificação, mas que não é autossuficiente e não parece, portanto, indicar diretamente os fundamentos da prática.

De um ponto de vista sociológico, os "fatos justificativos" se caracterizam também pelo fato de desenvolverem um problema, por assim dizer, "para frente" ou "para o exterior" da própria prática. Eles exploram certas consequências (desejáveis/lamentáveis) da prática social em questão, eles constroem novos problemas, etc. Pode-se dizer, tomando emprestada uma expressão de Husserl ${ }^{41}$, que os fatos justificativos tendem a desviar nossa atenção na direção de outros estados-de-coisa a conhecer. Eles nos afastam do "fundamento". Assim, a opinião do público nos leva a outros estados-de-coisa a conhecer: será que o público realmente pensa do modo que se diz que ele pensa? Modificaria sua opinião se recebesse informações adicionais sobre os efeitos dessa prática? Essas questões, apesar de muito importantes, nos levam a deixar para trás a pesquisa sobre os fundamentos.

Importante notar que a questão do efeito/não efeito da dissuasão é mais complexo, pois ele pode se referir aos fundamentos. De um lado, a questão nos conduz a outros estados-de-coisa a conhecer, mas, de outro lado, a resposta pode dizer respeito a um argumento autossuficiente que é utilizado como fundamento. Evidentemente, se o sistema político e o sistema de direito não utilizam esses resultados contra o fundamento, este permanece válido (do ponto de vista desses sistemas). E se eles abandonam o fundamento criticado (a teoria da dissuasão) para se apoiar sobre outro fundamento não criticável empiricamente (teoria da retribuição), a prática não perde todos os seus fundamentos.

É por essa razão que a pesquisa dos "fatos justificativos" desvia a atenção do observador dos fundamentos dessa prática. Há uma espécie de paradoxo no fato de avançar no plano das informações: nós obtemos mais informação (sobre a satisfação/ não satisfação do público, etc.), mas nós caminhamos em direção ao exterior da prática em si mesma, perdendo de vista as ideias e as teorias sobre 41 Husserl, E. (1893-1912). La phénoménologie de I'attention. Textes issus du fonds posthume. Paris: Librairie Philosophique J. Vrin, 2009. 
as quais ela repousa. Por um lado, exploramos outras dimensões ou aspectos de uma prática; por outro, perdemos de vista seu suporte essencial. Nós não identificamos os próprios fundamentos da prática e não nos aprofundamos nossa reflexão sobre eles. Nossa atenção concentra-se em outro lugar. É verdade que a referência ao fundamento pode acompanhar a observação do que é acessório, mas então ela o faz "num modo acessório" para retomar algumas observações de Husserl ${ }^{42}$. Será, então, outra questão, e não aquela relativa ao fundamento, que desempenhará "o papel de um motor do processo cognitivo"43.

segundo critério é complementar ao primeiro. Tenhamos em mente que o fundamento de uma prática social é aquilo que oferece ao que é fundado "um valor de aprovação muito característico: aquilo que é "sem fundamento" é ilegítimo ou quimérico; aquilo que é fundado é justo ou sólido" ${ }^{44} \mathrm{~A}$ hipótese de trabalho aqui é que o fundamento da pena mínima deve estar entre as ideias que transmitem um "forte valor de aprovação" como regra geral. A questão aqui será a seguinte: quais são as ideias que, quando evocadas, levam frequentemente as pessoas a aceitarem, em princípio, essa prática?

A dificuldade de aplicação desse critério decorre do fato de que, em situações excepcionais, os fatos justificativos podem fornecer um valor forte para um posicionamento contrário a uma prática social dominante. Por exemplo, um aumento extraordinário na população carcerária pode fornecer um forte valor para um posicionamento contrário a essa prática. No entanto, é possível ver que a taxa de encarceramento não constitui, em si mesma, um argumento em favor dessa prática (ou contra ela).

O terceiro critério pode comportar exceções, mas ele nos ajudou no processo de identificação dos fundamentos. Já sabemos historicamente que a prática da pena mínima foi oficialmente atualizada em várias jurisdições ocidentais durante o

42 Para sermos mais precisos, digamos, tomando emprestada a linguagem de Husserl (18931912), que o fundamento, mesmo quando é apreendido por uma "visão dita geral", não está mais presente como "visão especial": Husserl, E. (1893-1912). La phénoménologie de I'attention. Textes issus du fonds posthume, 2009, p. 108.

43 Husserl, E. (1893-1912). La phénoménologie de l'attention. Textes issus du fonds posthume. Paris: Librairie Philosophique J. Vrin, 2009, p. 104.

44 LALANDE, A. Fondement. In: LALANDE, A (Ed.). Vocabulaire technique et critique de la philosophie, 1968, p. 364. 
século XIX (Brasil, Canadá, Estados-Unidos, França). De acordo com esse critério, é de esperarmos cognitivamente que as ideias que dão a "razão de ser" dessa prática já estejam presentes e visíveis nas comunicações. Aqui, a hipótese de trabalho é que as ideias fundadoras são ao menos contemporâneas de uma prática que se difundiu em várias jurisdições (embora não possam explicar esse nascimento). Há uma segunda hipótese de trabalho, ligada à anterior: é que a densidade de um fundamento é dada por sua historicidade, isto é, pela "longa duração" das ideias. Podemos também dizer: por sua recorrência nas comunicações de um sistema social de referência. Quanto mais um sistema social repete para si mesmo certas ideias associando-as a uma prática, mais essas ideias se condensam e ganham em credibilidade. Os fatos justificativos, ao contrário, não são caracterizados pela mesma longevidade que a institucionalização da prática (eles não duram no tempo) e têm, por consequência, menos densidade ou historicidade.

O quarto critério é também auxiliar. A hipótese de trabalho aqui é que as ideias ou teorias que constituem o fundamento de uma prática encontram-se em todo lugar onde existe essa prática. Se a pertinência da justificativa (ou do argumento) está circunscrita às características de uma região ou de algumas jurisdições enquanto a prática existe em outras regiões em que não encontramos essa característica, essa justificativa tem boas chances de ser um simples "fato justificativo".

Enfim, o argumento que serve para fundar uma prática social deve poder se aplicar a todas as variedades dessa prática. Desse modo, no caso da pena mínima, ele deve poder se aplicar àquelas que se dirigem aos juízes de aplicação das penas ou às autoridades correcionais (gestão da pena) e mesmo àquelas que são construídas exclusivamente com a sanção de multa (sem a pena de prisão). As teorias da retribuição e da dissuasão passam essa prova, mas uma série de argumentos a favor ou contra essa prática não passam. Então, o argumento da satisfação da vítima utilizado em favor dessa prática parece ser pouco pertinente para justificar a pena mínima de multa ou as penas de prisão de curta duração (três a seis meses, por exemplo).

Cremos poder afirmar que os fundamentos dessa prática da pena mínima (e também da pena única e bipartida ou tripartida) são dados por duas (ou 
três) teorias da pena e por uma teoria (do século XVIII) acerca da separação dos poderes. Essas são as únicas justificativas encontradas que satisfazem os cinco critérios para identificar um "fundamento". As duas teorias da pena são as da retribuição e da dissuasão. A terceira, em relação à qual temos algumas dúvidas, é a teoria da denunciação ou da reprovação social (voltaremos a este ponto mais adiante). Trataremos aqui a $n^{\circ} 6$ e nos dois pontos seguintes $\left(n^{\circ} 7\right.$ e $\left.n^{\circ} 8\right)$ das teorias da pena e, no ponto 9 , da teoria da separação dos poderes.

Lembremos rapidamente que a teoria da retribuição sustenta que a pena deve infligir uma "tarifa proporcional de sofrimento" para "fazer justiça" e que essa teoria é indiferente ao fato de o culpado ter ou não reparado (ou reatado suas relações com) a vítima, poder ou não ser libertado se o juiz o considerar reabilitado, etc. A prática da pena mínima apoia-se em e conta essencialmente com a seguinte ideia dessa teoria: ao menos uma tarifa mínima de sofrimento, mesmo se essa tarifa for de muito longa duração (considerando que o crime seja considerado grave). A teoria enfatiza também que a punição é uma "obrigação moral imperativa": é necessário punir, sem exceção, todos os transgressores considerados culpados. Ela presta também seu apoio ao princípio da pena mínima absoluta. Essa teoria apoia também a iniciativa - ou não a contradiz fortemente - de punir mais severamente os reincidentes (contanto que isso seja feito sem produzir uma desproporção mais ou menos grosseira entre a gravidade do crime e a pena). Na realidade, compreendemos frequentemente que ela aceita a ideia de que a "culpa aumenta com a repetição das transgressões". E como essa teoria constrói uma ligação estrita, quase "hidráulica", entre a severidade da pena e o grau de culpa, quanto mais o dito grau é visto como "mais elevado", mais sofrimento deve ser infligido pela punição. É o que a teoria prática recomenda às autoridades políticas e jurídicas.

A teoria moderna ${ }^{45}$ da dissuasão (ou da prevenção) sustenta que o sofrimento infligido pela pena deve ultrapassar (pelo menos um pouco) as vantagens do crime

45 Referimo-nos aqui à versão de Beccaria e Bentham, que se tornou a versão dominante depois da segunda metade do século XVIII. Essa versão opõe-se àquela pré-moderna da "doutrina da severidade máxima", que não desapareceu inteiramente. Sobre a "doutrina da severidade máxima", ver: Radzinowicz, L. A History of English Criminal Law and its Administration from 1750. 1. The Movement for Reform. London: Stevens \& Son Limited, 1948. Ver também: Pires, Alvaro P.. La doctrine de la sévérité maximale au Siècle des Lumières. In C. Debuyst, F. Digneffe \& A. P. Pires (eds.), Les savoirs sur le crime et la peine. La rationalité pénale et la naissance de la criminologie. Bruxelles: De Boeck Université, 1998, v. 2, 53-82. 
para poder servir de freio ou de obstáculo aos criminosos potenciais eliminando a sua audácia de cometer um crime. A teoria comunica às autoridades que uma pena "que inflige sofrimento suficiente protege a sociedade", e somente essas penas o fazem. A teoria tenta convencer as autoridades que a pena do direito criminal é capaz de controlar as operações mentais dos sistemas psíquicos e, particularmente, se ela é "certa" (e proporcionalmente severa); isto é, aplicada sem exceção ou com a menor exceção possível. Para essa teoria, os reincidentes devem ser punidos mais severamente, pois a sua reincidência "mostraria" que a primeira punição dada não foi suficientemente forte para eliminar a sua audácia. Todavia, há um limite: ela sustenta também a necessidade de respeitar certa escala de proporcionalidade entre os crimes e as penas. A ideia da teoria é que os diversos níveis de gravidade dos delitos não devem se confundir. Se punirmos com severidade excessiva os crimes mais leves (até mesmo entre os reincidentes), estimularemos a perpetração de crimes mais graves, já que as suas penas se tornarão equivalentes.

Essas duas teorias têm em comum o fato de que são inteiramente indiferentes à inclusão social dos indivíduos. Isso significa que o critério da inclusão social não importa para decidir a pena. A teoria da dissuasão se constrói a partir de um conhecimento muito rudimentar e simplista do modo de funcionamento da "racionalidade dos indivíduos" e dos sistemas psíquicos. Além do mais, ela pressupõe tantas coisas por parte do mais comum dos mortais que raramente alguém poderia efetivamente lhe corresponder nas condições da vida cotidiana ${ }^{46}$. Mas nada disso é espantoso: essa teoria precede o nascimento e o desenvolvimento das ciências humanas. As duas teorias foram e são utilizadas para fundar essa prática e elas são chamadas a intervir de forma alternativa ou cumulativa pelo sistema político e pelo sistema de direito.

Evidentemente, os enunciados (premissas) dessas teorias não prescrevem direta e explicitamente as penas mínimas como tais (mais globalmente: eles não prescrevem diretamente nenhuma prática punitiva específica). A decisão de criar penas mínimas legislativas é uma decisão "inspirada por essas teorias". Dito de 46 Comparar com as observações de Schutz e Luckmann: Schutz, A. \& Luckmann, T. The Structures of the Life-World, vol. II. Evanston, Northwestern University Press, 1983, p. 57 e ss. 
modo prosaico: certos sistemas psíquicos, ao tomar conhecimento da teoria, produzem a ideia da pena mínima, e a realização dessa ideia leva outros a repetila. Ao interiorizar as ideias da teoria, pode-se vir a ter (ou não) a ideia de criar penas mínimas. Ademais, quando mobilizamos essas teorias para justificar a prática da pena mínima, aumentamos a probabilidade da sua aceitação. Se uma autoridade política diz: "Nós criamos a pena mínima para obter mais votos", essa justificativa, por si mesma, não favorece a aceitação da prática (no exterior do partido político). Mas se ela diz: "Nós criamos esta pena para proteger a sociedade contra a criminalidade" e/ou "para assegurar que a punição será proporcional ao crime", ela aumenta a probabilidade que esta pena seja aceita pelo público e pelo sistema de direito criminal. A "finalidade" da escolha política confunde-se com a "finalidade" da pena (mínima) atribuída pelas teorias da pena e tem mais chances de ser considerada como "válida".

No Canadá, as teorias da retribuição e da dissuasão eram absolutamente presentes e dominantes no século XIX mas, no entanto, houve relativamente pouca atenção fixada sobre as penas mínimas até a lei contra as drogas de 1961 e a abolição da pena de morte em 1976. É uma das razões pelas quais um fundamento não explica a atualização (ou a abolição) da prática social específica que ele funda. Metaforicamente falando: os fundamentos de um edifício não nos levam a construir o edifício " $X$ ". Podemos construí-lo ou não e podemos construir inúmeros ou muito pouco. Ademais, podemos, sobre um mesmo fundamento, construir "tipos de edifícios" que sejam relativamente diferentes uns dos outros: pena única, pena bipartida, pena mínima absoluta, pena mínima com isenções não estritas, etc.

Afirmamos que essas duas teorias fundam essa prática porque elas parecem ser as únicas capazes de fornecer uma "razão de ser" para todas as modalidades, variantes genéricas e formas concretas da pena mínima: aquela que se dirige ao tribunal e à gestão das penas; a que é absoluta e a que não o é; a que estipula uma pena (curta ou longa) de prisão e / ou exclusivamente de multa.

Por outro lado, vale a pena repetir, isso não quer dizer que essas teorias conferem seu assentimento incondicional a qualquer pena mínima concreta fabricada pelo 
sistema político. Por exemplo, essas teorias, na sua forma refletida, não apoiam uma pena mínima de 7 anos para o furto de uma garrafa de leite ou para a importação de um maço de cigarros de maconha. Mas elas podem ser utilizadas por um governo para justificar essas penas e elas não podem "resistir" a esse (mau) uso. Todavia, pode surgir uma resistência se o direito utilizar essas mesmas teorias para criticar a desproporção grosseira dessas penas. Mas se o direito julgar que importar um maço de cigarros é "um crime muito grave" porque isso "estaria ligado" (segundo sua representação) a todas as mortes causadas pelas drogas no planeta, não haverá resistência (nesse momento), mas assentimento: a justificativa do político (boa ou má) é recebida positivamente pelo sistema de direito criminal. É uma das funções dessas teorias: fazer aceitar a decisão de um sistema (político) por outro (direito criminal) e contribuir, para o bem e para o mal, a uma coordenação entre esses dois sistemas.

Voltemos à nossa imagem: os fundamentos podem "reagir contra" uma construção em particular. Por exemplo, os fundamentos de um edifício de 10 andares "toleram mal" um edifício de 20 andares. Sem abandonar a imagem: os fundamentos "exigem" certa proporcionalidade para "sustentar" a construção " $X$ ". Mas o engenheiro pode ignorar essa exigência e o edifício pode ficar (ou não) milagrosamente de pé, pelo menos por um tempo. É por essa razão que a jurisprudência pode empregar essas teorias (que fundam uma prática) não somente para conservá-la, mas também para questioná-la em algumas de suas manifestações concretas. É também por essa razão que um indivíduo que contribui para as ideias retributivistas (ou da teoria da dissuasão) pode, sem abandonar essas ideias, criticar ao mesmo tempo certas formas de pena mínima. É preciso distinguir entre "aceitar as ideias que fundam" e "aceitar a pena mínima" ou certas formas ou manifestações concretas dessa prática. Um indivíduo pode achar que certas penas mínimas são demasiado elevadas ("desproporcionais"); que a pena mínima legislativa absoluta (obrigatória) produz injustiças, mas que a pena mínima não absoluta e não estrita não coloca problemas, etc.

Ilustremos a partir de um único exemplo como essas teorias desempenham um papel na aceitação-reprodução fática dessa prática. Trata-se aqui da declaração 
de um ministro canadense da Justiça ao Senado em 1952. Nessa declaração, o ministro opunha-se ao ponto de vista da Royal Commission on the Revision of the Criminal Code, que recomendava a abolição de todas as penas mínimas, e a teoria que ele selecionou e atualizou na sua comunicação é a da dissuasão: "[...] consideramos que, em razão do seu efeito dissuasivo, as penas mínimas não deveriam ser inteiramente abolidas [...]"47. Vemos que essas teorias não são simplesmente utilizadas para fazer aceitar uma nova pena mínima, mas também para resistir contra a sua abolição.

Identificamos duas ressalvas que poderíamos fazer às nossas afirmações sobre essas duas teorias da pena como fundamento dessa prática. A primeira é a seguinte: a teoria da pena da neutralização não constituiria também um fundamento?

Lembremos que, na sua expressão mais elementar, a teoria da neutralização sustenta que, em certos casos e por razões específicas, pode parecer necessário neutralizar certos indivíduos "que representam uma ameaça séria para a vida e a segurança pessoal dos outros"48. Nesse sentido estrito, a teoria legitima exclusivamente certas prestações específicas do tribunal no que concerne à determinação da pena.

No entanto, de um ponto de vista empírico, é certo que a teoria da neutralização foi empregada para justificar certas formas concretas de pena mínima. Foi especialmente o caso de certas leis estadunidenses conhecidas pelo nome de "leis das três faltas" ("three strikes and you're out"). No âmbito dessas leis, um indivíduo foi condenado a uma pena mínima de 27 anos por ter tentado vender baterias roubadas que valiam US\$ 90,00 (essa era sua terceira pequena infração) ${ }^{49}$. Essas leis foram justificadas pela teoria da neutralização (e secundariamente pela teoria da dissuasão) ${ }^{50}$. Porém, examinando mais de perto, vemos que a teoria da 47 Citado em DOOB, A. N.; CESARONI, C. The Political Attractiveness of Mandatory Minimum Sentences, 2001, p. 289.

48 Commission de réforme du droit du Canada (1976). Imprisonment and Release. Working Paper 11. In Commission de réforme du droit du Canada (Ed.), Studies on imprisonment (1-46). Ottawa: Minister of Supply and Services Canada, 1976, p. 11-12 (tradução nossa).

49 Esse exemplo é dado, entre outros, por. DOOB, A. N.; CESARONI, C. The Political Attractiveness of Mandatory Minimum Sentences, 2001, p. 294-295.

50 É verdade que, no que tange à teoria da dissuasão, Beccaria e Bentham se sentiriam ofendidos. Mas a versão pré-moderna dessa teoria (doutrina da severidade máxima) pode se aplicar. 
neutralização não serve como fundamento dessa prática no seu conjunto. Ela não se aplica às penas mínimas construídas com multa nem às construídas com uma curta pena de prisão. É que o argumento da teoria "de impedir a pessoa condenada de cometer uma nova infração durante o seu encarceramento" só tem um mínimo de sentido para as penas muito longas ou para situações muito individualizadas (o que a pena mínima não faz). Portanto, essa teoria não tem um alcance fundacional suficientemente amplo. Ela serve, no máximo, de fundamento ad hoc para as penas mínimas legislativas mais radicais e absurdas (aquelas que não são apoiadas nem pela teoria da retribuição nem pela teoria moderna da dissuasão).

A segunda ressalva ofereceu mais dificuldades para nós e nossas dúvidas em relação a ela não foram inteiramente dissipadas. Sua formulação é a seguinte: a teoria da denunciação (ou da reprovação social) não constitui também um fundamento dessa prática?

Duas razões favorecem uma resposta negativa. A primeira razão é que essa teoria emerge como teoria diferenciada das outras duas (retribuição e dissuasão) somente na segunda metade do século XIX. As penas mínimas já estavam instaladas e fundadas. Além disso, essa teoria só se tornará visível e fortemente institucionalizada pelo sistema político e pelo sistema de direito criminal a partir da segunda metade do século $X X^{51}$. No entanto, isso não afasta inteiramente a possibilidade de que ela seja um novo fundamento para uma velha prática. $E$, até certo ponto, ela parece efetivamente desempenhar esse papel.

A segunda razão para não incluí-la entre os fundamentos é a seguinte: existem pelo menos duas versões dessa teoria, mas, ao menos em algumas jurisdições do common law, o sistema político e o sistema de direito criminal atualizam, de modo predominante sobretudo a versão que valoriza as penas mais severas para os crimes considerados os mais graves ${ }^{52}$. Essa versão sustenta a necessidade das 51 Lachambre, S.. L'émergence et l'institutionnalisation de la théorie de la dénon- ciation en droit criminel. Thèse de doctorat, Département de criminologie, Université d'Ottawa, 2011 (documento provisório).

52 Não podemos discutir isso em detalhes, mas a teoria selecionada, por exemplo, não é a que foi proposta pela Comissão de Reforma do Direito do Canadá (1976). Esta última (que tem o mesmo nome) não autorizava penas mínimas legislativas. A teoria da Comissão dirigia-se exclusivamente ao tribunal. Além do mais, ela não autorizava penas superiores a 3 anos de prisão com a única finalidade de denunciar um comportamento. 
penas severas (de prisão ou de morte) "para dar exemplos espetaculares" de inflição de sofrimento. Ela parece, portanto, menos pertinente para fundar a pena mínima construída com a pena de multa. Por outro lado, essa teoria contribuiu a fundar a pena construída com penas severas de prisão, além de ser utilizada pelos movimentos sociais para reivindicar penas severas que parecem responder aos seus interesses.

Contudo, identificamos também uma razão que milita em favor de uma resposta positiva. Nas jurisdições de tradição jurídica romano-germânica, esta teoria da "denunciação"53 parece estar menos orientada especificamente em favor das penas particularmente severas. Em virtude disso, nós optamos, nesse momento, incluí-la entre as teorias que contribuem a fundar essa prática, pois ela constitui um fundamento marginal para a pena mínima de multa cujo valor não é elevado.

A última dificuldade em relação à identificação dos fundamentos pode ser apresentada do seguinte modo: o princípio da igualdade perante a lei pode fundar a prática legislativa da pena mínima? Este princípio é também associado empiricamente à pena mínima, sendo também contemporâneo à emergência dessa prática. De fato, ele satisfaz igualmente aos cinco critérios empíricos indicados. Sublinhemos particularmente o critério da autossuficiência: "a justiça exige a igualdade perante a lei".

À questão "por qual razão criar ou conservar as penas mínimas?", podemos então responder, com as observações de Gabriel Tarde ${ }^{54}$ : "A desgraça é que individualizar a pena é desigualá-la para delitos iguais, e é bom fazer entrar em consideração o sentimento de injustiça aparente que essa desigualdade não pode deixar de fazer com que sintam os condenados, e até um grande número dentre eles, e mesmo a massa ignorante do público".

Mais uma vez, não nos é possível desenvolver esse tema aqui. Fazê-lo nos exigiria comparar o lugar dos valores "igualdade" e "liberdade" no direito criminal.

53 A doutrina utiliza sobretudo as denominações "teoria da reprovação social" ou " da prevenção geral positiva"

54 TARDE, Gabriel. Préface. In: SALEILLES, R. (ed.). L'individualisation de la peine. Étude de criminalité sociale. Paris: Librairie Félix Alcan, 1927, xi-xvi. 
Digamos simplesmente que há diferentes formas de conceber e de construir o valor igualdade em direito criminal. Por exemplo, podemos oferecer os mesmos critérios de avaliação a todos os condenados. Mas a maneira pela qual Tarde construiu a igualdade - "a pena deve ser igual à infração" - é extraída de uma das teorias da pena (nesse caso, a teoria retributivista). O argumento da igualdade que é utilizado para legitimar a pena mínima (e única) é invariavelmente extraído ou da teoria retributivista ou da teoria da dissuasão. Nossa conclusão é, portanto, que esse discurso sobre a igualdade integra efetivamente os fundamentos da pena mínima, mas na medida em que se constitui um "fragmento avulso" das próprias teorias da pena. Com efeito, essa maneira de conceber a igualdade é um resultado dessas teorias. São as duas teorias (retribuição e dissuasão) que fundam, por sua vez, o argumento sobre a igualdade entre a infração e a pena (retribuição) ou entre a gravidade do crime e a severidade da pena (dissuasão). Contudo, como essa justificativa pelo princípio da igualdade circula frequentemente sem referência explícita às teorias da pena, nós vamos incluí-la também de forma separada no quadro 4.

\section{A QUESTÃO DA SEPARAÇÃO DOS PODERES}

Agora, rapidamente, o que acontece com a teoria da separação dos poderes? Referimo-nos a uma teoria do século XVIII que encontramos, entre outros, em Montesquieu ${ }^{55}$ e Beccaria ${ }^{56}$. Em matéria criminal, essa teoria atribui ao juiz a tarefa de determinar se um acusado é culpado ou não, mas atribui ao legislador (sistema político) a tarefa de determinar a pena. Conforme a interpretação que ela recebe, essa teoria pode avalizar a ideia de que o parlamento goza de legitimidade plena para determinar a pena criminal, podendo atribuir ou não aos tribunais certo campo decisório ${ }^{57}$.

Doyle $^{58}$ nos mostra, de modo interessante, como a Corte Suprema dos EUA parece ao mesmo tempo aceitar essa teoria (em relação à pena única e

55 MONTESQUIEU, C. S. (1748). De l'esprit des lois. Paris: Garnier, 1973.

56 BECCARIA, C. (1764). Des délits et des peines. Genève: Librairie Droz, 1965.

57 Beccaria (1764, §III, p. 10) parece autorizar o juiz a reduzir a pena, mas não a aumentá-la, enquanto Montesquieu adota uma posição mais inflexível: nem mais nem menos.

58 DOYLE, Charles. Federal Mandatory Minimum Sentencing Statutes: A List of Citations with Captions, Introductory Comments, and Bibliography, 2003, p. 47-118. 
mínima) e consagrar um princípio que poderia contradizer essa teoria e retirar a legitimidade dessa prática (e que ainda pode fazê-lo). Em uma de suas decisões, a Corte disse que o "Congresso tem o poder de definir as punições criminais sem dar aos tribunais nenhuma discricionariedade a respeito da pena" (United States v. Chapman, 500 U.S. 453, 467 (1991), grifos nossos). Numa outra decisão, ela sustenta que "permanece um princípio fundamental do nosso modelo constitucional o fato de que um ramo do Governo não pode imiscuir-se ['intrude upon'] nas prerrogativas centrais de outro ramo". A Corte afirma a separação dos poderes, mas aceita ao mesmo tempo uma forma de ingerência ou intervenção radical do político na sentença do direito: aquela que chega a retirar dele toda discricionariedade acerca da sentença. Tudo acontece como se a determinação da pena não pertencesse às prerrogativas centrais do tribunal. Em suma, não somente a pena única, mas igualmente a pena mínima com ou sem cláusula de isenção, são aceitáveis para essa teoria. Ela legitima todas essas formas de intervenção política na sentença do direito.

Montesquieu e Beccaria observam o papel do juiz no momento de indicar a pena como o mais próximo possível do de um "aplicador mecânico" da pena estipulada pelo legislador. Daí a célebre fórmula de Montesquieu ${ }^{59}$ : "[...] os juízes da nação são apenas, como dissemos, a boca que pronuncia as palavras da lei; seres inanimados que não podem moderar nem a força nem o rigor das mesmas" (grifo nosso). A pena mínima (e única) é justamente aquilo que servirá de obstrução à moderação do juiz. Zenati mostra que, no âmbito dessa teoria, "reconhecer ao juiz um poder de apreciação" é visto como algo que gera "um risco de arbitrariedade"60. Do ponto de vista dessa teoria, o legislador fica cego em relação a sua própria arbitrariedade e vê apenas a do juiz; ou ainda o legislador vê sua arbitrariedade, mas a tolera. A teoria prega a necessidade de cortar "toda faculdade de iniciativa" (Zenati) do juiz. Evidentemente, na sua forma mais radical, a teoria logo se tornará obsoleta. Mas ela continua a legitimar essas duas práticas (pena única/mínima).

59 MONTESQUIEU, C. S. (1748). De I'esprit des lois. Paris: Garnier, 1973, LXI, Cap. VI, p. 176.

60 ZENATI, F. La jurisprudence. Paris: Dalloz, col. Méthodes du Droit, 1991, p.46. Esse autor, no seu excelente trabalho sobre a jurisprudência, cita também o trecho de Montesquieu reproduzido acima. 
Fica claro que, segundo essa teoria, a pena é mais uma "questão política" que uma "questão de direito". Não vamos descrever aqui a maneira como o sistema de direto criminal acabou por interiorizar e aceitar essa teoria. Mas ela produz, com relação ao ofício do juiz, uma verdadeira capitis diminutio (perda de autoridade) quanto a uma de suas atribuições que, no entanto, é central61. a proteção da liberdade dos indivíduos e a determinação de sanções "justas" para o caso concreto (sem submeter-se a um ritual político sacrificatório). Mas como é possível sustentar a prática da pena única e mínima legislativa sem essa teoria que atribui ao sistema político o direito de determinar a pena do sistema de direito? Pelo menos à primeira vista, ela também parece fundar essa prática. Ela possui uma densidade cultural e fornece um ponto de apoio para o assentimento desse tipo de intervenção; ela é também aplicável em todos os lugares onde essa prática existe e chega mesmo a preceder um pouco historicamente o modelo da pena mínima. E ela se aplica a todas as variedades da pena mínima legislativa.

Todavia, apareceram dois problemas na operacionalização da distinção fundamento/fato justificativo: somente um deles será apresentado aqui.

Essa dificuldade é a seguinte. Mesmo no plano estritamente legislativo, essa teoria da divisão de poderes é insuficiente para fundar tal prática. Ela não satisfaz ao primeiro critério que é capital. O argumento da "competência do legislador" para determinar a pena só faz deslocar o problema do fundamento. Para percebêlo, basta imaginar a seguinte pergunta feita ao legislador: "Por que motivo você criou essa pena mínima?". A resposta "porque isso é da minha competência" não é nem suficiente nem satisfatória como fundamento. De fato, se o legislador instaurasse uma prática que consistisse em criar várias leis racistas, o fato de ter uma "competência para criar leis" não bastaria para fundar essa prática. Ele precisa apresentar os motivos por trás das suas decisões específicas. De fato, a teoria justifica exclusivamente a ingerência do sistema político (legislador) numa atribuição central do direito (juiz). Ela autoriza o legislador a retirar o poder discricionário do juiz de reduzir o quantum das penas e de escolher outras menos

61 Mais uma vez, beneficiamo-nos aqui das reflexões feitas por ZENATI, F. La jurisprudence. 1991, p.46 
severas, mas ela não fornece as razões para fazê-lo. O fundamento da pena mínima depende ainda da credibilidade das teorias da pena que a sustentam.

Apesar dessa dificuldade central, existem razões para ver nessa teoria uma contribuição para os fundamentos da pena única, bipartida e mínima.

Lembremos que essa teoria não cria a separação dos poderes ${ }^{62}$ : ela simplesmente atribui papéis e tarefas no interior dessa separação (fática) dos poderes. Ela diz, por exemplo, "x cabe ao poder executivo", "y ao poder legislativo" e "z ao poder judiciário". Ela proíbe também que os indivíduos ocupem dois papéis simultaneamente, por exemplo, ser deputado e juiz ao mesmo tempo. Mas essa teoria, em matéria criminal, não se limita a atribuir ao legislador uma competência para fazer leis, nem mesmo exclusivamente uma competência para limitar o poder dos tribunais de punir de modo mais severo. Ela autoriza o legislativo a subtrair integralmente (ou a limitar) o poder discricionário dos juízes para selecionar sanções menos restritivas e/ou quantidades menos pesadas. A teoria autoriza o sistema político a intervir radicalmente no campo central das prerrogativas do judiciário e, o que é mais importante ainda, a opor-se à redução do poder de moderação e de proteção jurídica do tribunal.

Ora, é forçoso reconhecer que, sem essa teoria, o poder legislativo não teria podido se autorizar a criar penas únicas, bipartidas e mínimas. O poder judiciário, utilizando as teorias da pena no campo das suas prerrogativas, poderia tê-lo feito, mas não o sistema político. A implicação prática dessa teoria da separação dos poderes é que ela funda, para o sistema político, uma possibilidade de ingerência radical na sentença do direito para reduzir sua capacidade de moderação e de proteção jurídica dos direitos.

Então, é graças a essa teoria caduca da separação dos poderes que esse tipo específico de intervenção política que cria penas únicas, bipartidas e mínimas, se transforma numa "expressão da democracia" e não do "autoritarismo". Logo, essa teoria é capital para fundar e legitimar essa forma "invasiva" de intervenção legislativa na sentença do direito. Ela dá um "valor de legitimação forte" àquilo que corre um grande risco de ser observado como uma ingerência autoritária e 62 ZENATI, F. La jurisprudence. Paris: Dalloz, col. Méthodes du Droit, 1991, cap. 2. 
antidemocrática. Quando empregamos a distinção democracia/autoritarismo para observar uma prática social, essa teoria nos leva a escolher a face "democracia" para situar uma prática que, de outra forma, correria grande risco de ser vista como autoritária $^{63}$. Sem essa teoria, poderíamos aceitar outras práticas não legislativas de pena mínima (na jurisprudência, por exemplo), mas não a prática legislativa.

Como conciliar então nossas duas observações? Essa teoria da separação de poderes seria um fundamento ou um simples fato justificativo? Diremos que, para o sistema político, essa teoria da separação dos poderes é, sob certos aspectos, um simples "fato justificativo" (ou uma justificativa acessória) e, sob outros aspectos, um "fundamento", isto é, um embasamento teórico fundamental. Com relação às penas únicas, bipartidas e mínimas em si mesmas, a teoria permanece um fato justificativo (acessório): essas práticas, mesmo implantadas pelo legislativo, precisam das teorias da pena para sustentá-las. Todavia, com relação à força ou à radicalidade da intervenção política nos assuntos do direito, essa teoria é um fundamento: ela dá a razão de ser e o ponto de apoio do nosso assentimento à radicalidade que a intervenção política adota. Em suma, essa teoria funda menos a pena mínima, bipartida e única que a radicalidade da intervenção política através da legislação na sentença do direito para impedi-lo de desempenhar seu papel. Ela funda o recurso ao médium "legislação" e a "radicalidade" dessa intervenção.

Essa radicalidade se caracteriza aqui por um conjunto de elementos estreitamente ligados uns aos outros: o sistema político entra no campo das prerrogativas centrais do direito (criminal) para limitar o uso de sanções menos draconianas e para cortar ou reduzir (com ou sem exceção) a capacidade desse sistema (direito) de controlar a radicalidade das exclusões sociais realizadas pelo sistema político em relação às pessoas que se tornaram então "corpos"64. Para dar uma ideia mais precisa, tudo acontece como se quiséssemos justificar um "esporte extremo": uma teoria é necessária para fundar o esporte e outra para fundar a dimensão "extrema". As teorias da pena fundam o "esporte" (as penas mínimas, únicas e bipartidas em si mesmas); a teoria da separação dos poderes do século

63 O título do capítulo de Zenati citado acima referente a essa teoria é: "A era do autoritário".

64 A distinção pessoa/corpo ou pessoa/indivíduo é utilizada por Luhmann: Luhmann, Niklas.

Globalization or World Society: How to Conceive of Modern Society? International Review of Sociology, 1997, 7 (1), p. 67-80. 
XVIII funda tudo que é "extremo", isto é, a eliminação absoluta do campo de discrição dos tribunais em matéria de pena, a redução desse campo a alternativas quase equivalentes umas às outras (morte/prisão perpétua; perpetuidade/25 anos) ou a redução desse campo por meio das penas mínimas de todo tipo. Elas diminuem assim a capacidade dos tribunais de decidir em favor da proteção dos direitos dos indivíduos condenados através da redução do quantum da pena e/ ou através da escolha de uma pena menos restritiva. É o poder de expressão moderador do direito que entra em curto-circuito ou é censurado.

O quadro 4 resume nossa reflexão a respeito dessa difícil questão dos fundamentos dessas práticas na sociedade-mundo desde o final do século XVIII.

Teorias e princípios que fundam a prática legislativa da pena mínima

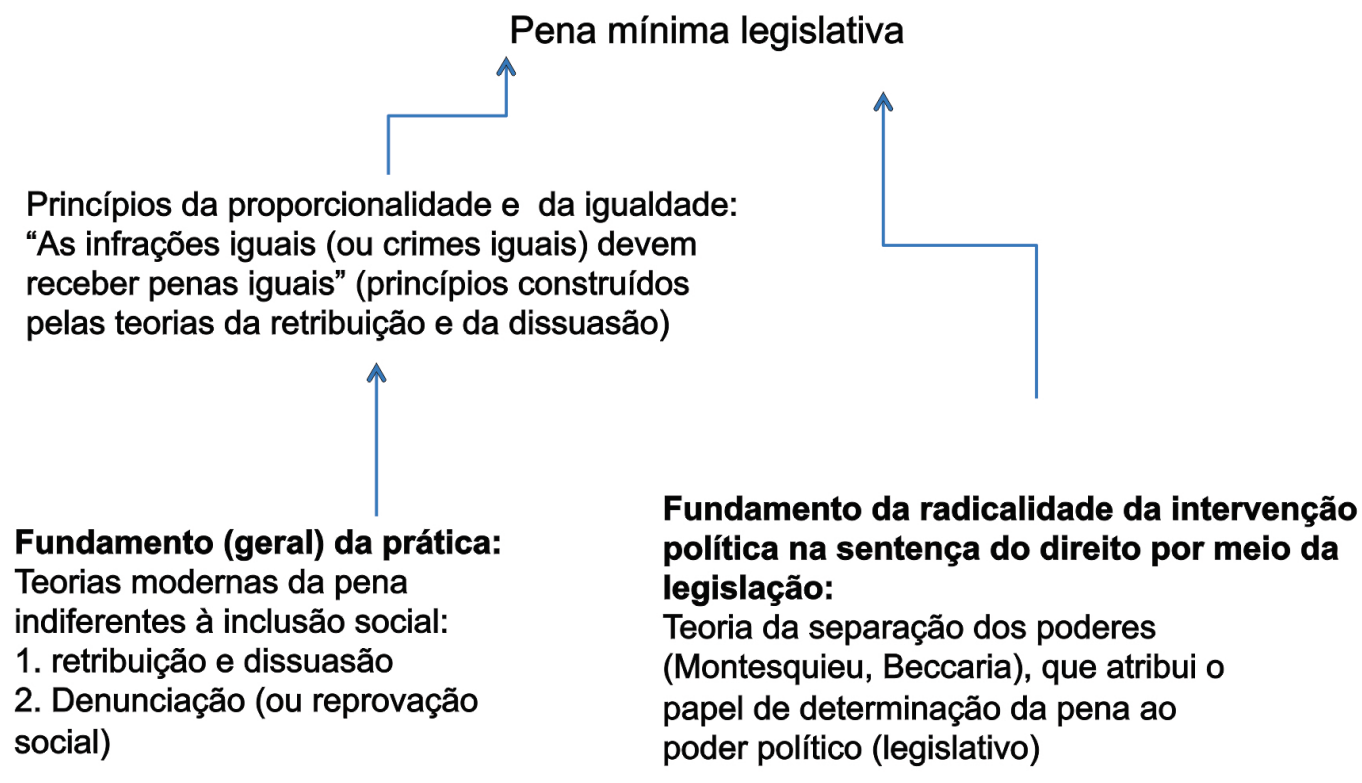

CONSIDERAÇÕES FINAIS

A título de conclusão, é interessante retomarmos aqui, resumindo-a, uma reflexão feita pelo jurista francês George Vidal65. Ele propõe uma nova concepção da separação de poderes e da legalidade do crime e da pena. No contexto dessa 65 Vidal, George (1906). Cours de droit criminel et de science pénitentiaire. Paris: Félix Alcan, 1928. 
reflexão, ele acentua a diferença fundamental entre uma pena mínima e uma pena máxima. Seu ponto de partida é que o princípio da legalidade não deveria ser abandonado. Sobre isso, ele escreve: "Seria, de fato, muito perigoso para a liberdade civil e a segurança individual abandonar o caráter de legalidade do direito penal"66. Contudo, para poder justamente assegurar a proteção dessa liberdade civil, o legislador (sistema político) não pode nem promulgar penas mínimas nem legislar sobre as circunstâncias atenuantes (para restringi-las). É como se essas duas atividades não se inscrevessem entre as suas tarefas. Não obstante, o legislador pode e deve, segundo ele, legislar (i) sobre os elementos constitutivos da infração, (ii) sobre as penas máximas aplicáveis e (iii) sobre as circunstâncias agravantes. Essas três práticas legislativas não intervêm no campo das prerrogativas centrais do sistema de direito porque não afetam as prestações de proteção que o sistema de direito deve garantir. Ao contrário, se essas práticas forem construídas com cuidado, elas podem ajudar o sistema de direito a desenvolver seu próprio quadro protetor operacional.

\section{REFERÊNCIAS DAS FONTES CITADAS}

Beccaria, C. (1764). Des délits et des peines. Genève: Librairie Droz, 1965.

Beck, U., \& Willams, J. (2000). Conversations with Ulrich Beck. Cambridge: Polity Press (édition de 2004).

Boisse, L. (1968). Commentaire critique au mot fondement. In A. Lalande (Ed.), Vocabulaire technique et critique de la philosophie (366-367). Paris: Presses Universitaires de France.

Brinkley, L. V. (2003). Preface. In L. V. Brinkley (Ed.), Mandatory Minimum Sentencing : Overview and Background. New York: Novinka Books.

Cavanagh, S., \& Teasely, D. (2003). Mandatory Minimum Sentencing for Federal Crimes: Overview and Analysis. In L. V. Brinkley (ed.), Mandatory Minimum Sentencing: Overview and Background (1-31). New York: Novinka Books.

Commission canadienne sur la détermination de la peine (1987). Réformer la sentence: une approche canadienne. Ottawa, Ministère des Approvisionnements et Services Canada.

66 Vidal, G. (1906). Cours de droit criminel et de science pénitentiaire, p. 1047. 
Commission de réforme du droit du Canada (1976). Imprisonment and Release. Working Paper 11. In Commission de réforme du droit du Canada (Ed.), Studies on imprisonment (1-46). Ottawa: Minister of Supply and Services Canada.

Crutcher, N. (2001). The Legislative History of Mandatory Minimum Penalties of Imprisonment in Canada. Osgoode Hall Law Journal, 39 (2 \& 3), 273-285.

Doob, A. N., \& Cesaroni, C. (2001). The Political Attractiveness of Mandatory Minimum Sentences. Osgoode Hall Law Journal, 39 (2 \& 3), 287-304.

Doob, A. N., \& Webster, C. M. (2003). Sentence Severity and Crime : Accepting the Null Hypothesis. Crime and Justice. A Review of Research, 30, 143-195.

Doyle, C. (2003a). Federal Mandatory Minimum Sentencing Statutes: An Overview of Legislation. In L. V. Brinkley (ed.), Mandatory Minimum Sentencing: Overview and Background (33-38). New York: Novinka Books.

Doyle, C. (2003b). Mandatory Minimum Sentences: Three Strikes in the Supreme Court - Ewing v. California and Lockyer v. Andrade. In L. V. Brinkley (Ed.), Mandatory Minimum Sentencing: Overview and Background (39-46). New York: Novinka Books.

Doyle, C. (2003c). Federal Mandatory Minimum Sentencing Statutes: A List of Citations with Captions, Introductory Comments, and Bibliography. In L. V. Brinkley (ed.), Mandatory Minimum Sentencing: Overview and Background (47-118). New York: Novinka Books.

Dumont, H. (1997). Désarmons les Canadiens et armons-nous de tolérance: Bannir les armes à feu, bannir les peines minimales dans le contrôle de la criminalité violente, procès sur une contradiction apparente. Criminal Law Review, 2 (43).

Durkheim, É. (1922). Éducation et sociologie. Paris: Presses Universitaires de France (édition de 2006).

Elias, N. (1984). Du temps. Paris: Fayard, 1997.

Foucault, M. (1975). Surveiller et punir. Naissance de la prison. Paris: Éditions Gallimard.

Foucault, M. (1980). La poussière et le nuage. In M. Foucault, Dits et écrits 1954-1988 (10-19). Paris: Éditions Gallimard (édition de 1994).

Gabor, T. and Crutcher, N. (2002). Les effets des peines minimales obligatoires sur la criminalité, la disparité des peines et les dépenses du système judiciaire. Ottawa, Ministère de la Justice du Canada. Disponível em http://www.justice.gc.ca/fra/pr-rp/sjc-csj/ajc-ccs/rr02_1/rr02_1.pdf (último acesso em 24.03.2016). 
Husserl, E. (1893-1912). La phénoménologie de l'attention. Textes issus du fonds posthume. Paris: Librairie Philosophique J. Vrin, 2009.

Lachambre, S. (2011). L'émergence et l'institutionnalisation de la théorie de la dénon- ciation en droit criminel. Thèse de doctorat, Département de criminologie, Université d'Ottawa (document provisoire).

Lalande, A. (1968). Fondement. In A. Lalande (Ed.), Vocabulaire technique et critique de la philosophie (364-366). Paris: Presses Universitaires de France.

Lascoumes, P., Poncela, P., \& Lenoël, P. (1989). Au nom de l'ordre. Une histoire politique du code pénal. Paris: Hachette.

Luhmann, N. (1997). Globalization or World Society: How to Conceive of Modern Society? International Review of Sociology, 7 (1), 67-80.

Machado, Maira; Pires, Alvaro; Ferreira, Carolina e Schaffa, Pedro. A complexidade do problema e a simplicidade da solução: a questão das penas mínimas. Brasília: Projeto Pensando o Direito MJ/PNUD, vol. 17, 2009. Disponível em http://pensando.mj.gov.br/publicacoes/ (acesso em 18.08.2016)

Machado, Maira. "Entre a lei e o juiz: os processos decisórios na definição de penas". Revista Brasileira de Ciências Criminais (no prelo).

Machado, Marta, Maira Machado e Fábio Andrade. Sispenas: Sistema de consulta sobre crimes, penas e alternativas à prisão. Série Pensando o Direito - Penas Alternativas, n 6, 2009. Disponível em http://pensando.mj.gov.br/publicacoes/ (acesso em 18.08.2016)

Montesquieu, C. S. (1748). De l'esprit des lois. Paris: Garnier, 1973.

Pires, A. P. (1998). La doctrine de la sévérité maximale au Siècle des Lumières. In C. Debuyst, F. Digneffe \& A. P. Pires (eds.), Les savoirs sur le crime et la peine. La rationalité pénale et la naissance de la criminologie (vol. 2: 53-82). Bruxelles: De Boeck Université.

Pires, A. P., \& Garcia, M. (2007). Les relations entre les idées: droits de la personne et théories de la peine face à la peine de mort. In Y. Cartuyvels, H. Dumont, F. Ost, M. van de Kerchove \& S. Van Drooghenbroeck (eds.), Les droits de l'homme, bouclier ou épée du droit pénal? (291336). Bruxelles: Bruylant et Facultés universitaires Saint Louis.

Radzinowicz, L. (1948). A History of English Criminal Law and its Administration from 1750. 1. The Movement for Reform. London: Stevens \& Son Limited. 
Raaflaub, W. R. (2006). Les peines minimales obligatoires. Service d'information et de recherche parlementaires. Canada: Bibliothèque du Parlement, PRB 05-53F. Disponível em http://www.bdp.parl.gc.ca/content/lop/researchpublications/prb0553-f.htm (último acesso em 24.03.2016).

Roberts, J. (2005). Peines d'emprisonnement obligatoires dans les pays de common law: quelques modèles représentatifs. Ottawa, Ministère de la Justice du Canada. Disponível em http://www. justice.gc.ca/fra/pr-rp/sjc-csj/ajc-ccs/rr05_10/rr05_10.pdf (último acesso 24.03.2016)

Schutz, A. \& Luckmann, T. (1973). The Structures of the Life-World. Evanston, Northwestern University Press.

Schutz, A. \& Luckmann, T. (1983). The Structures of the Life-World, vol. II. Evanston, Northwestern University Press.

Tarde, G. (1898). Préface. In R. Saleilles (ed.), L'individualisation de la peine. Étude de criminalité sociale. Paris: Librairie Félix Alcan, 1927 (xi-xvi).

Tonry, M. (1992). Mandatory Penalties. In M. Tonry (ed.), Crime and Justice: A Review of Research (vol. 16, 243). Chicago: University of Chicago Press.

Vidal, G. (1906). Cours de droit criminel et de science pénitentiaire. Paris: Félix Alcan, 1928.

Zenati, F. (1991). La jurisprudence. Paris: Dalloz, col. Méthodes du Droit.

Recebido em: mar/2016 Aprovado em: ago/2016 